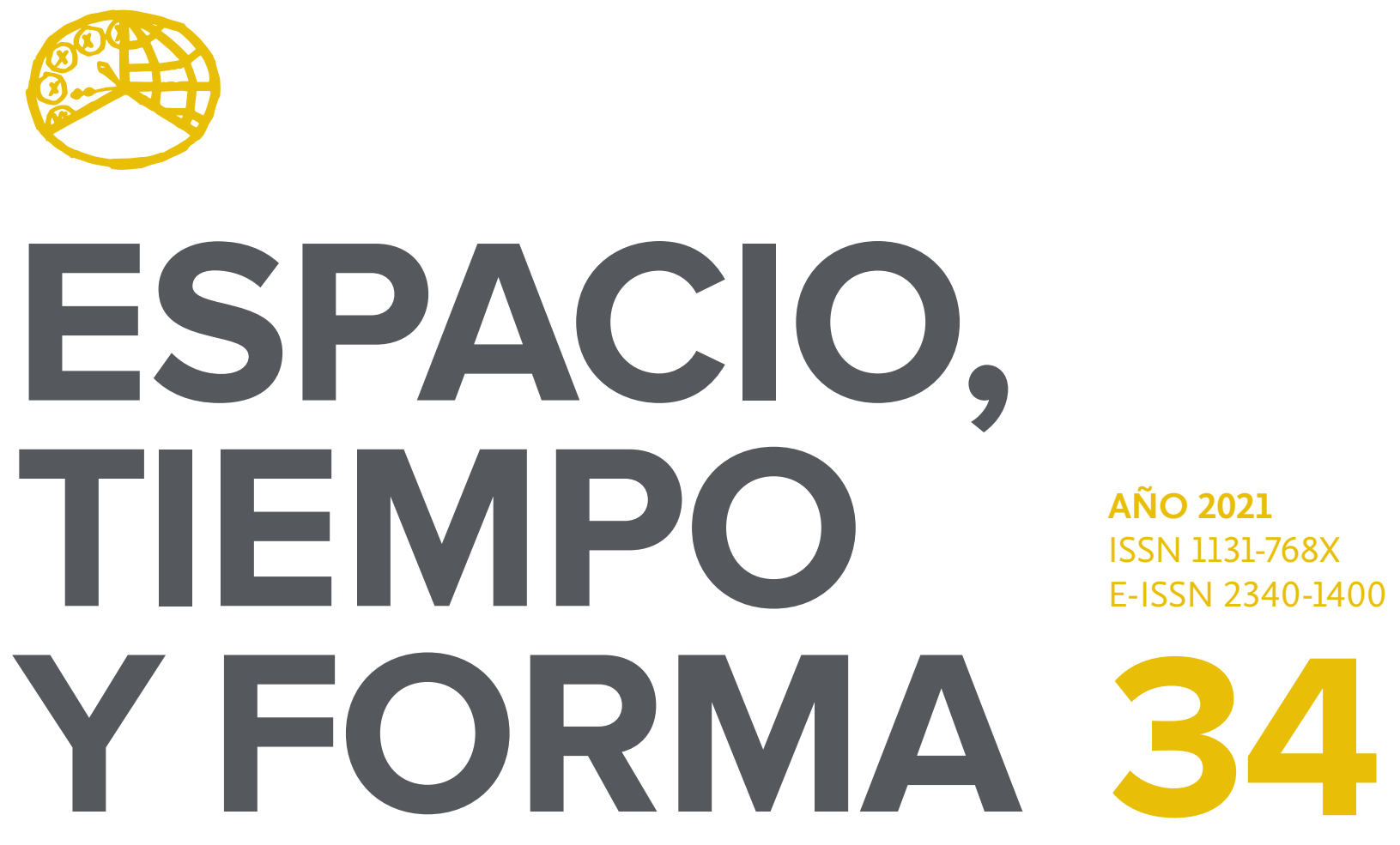

SERIE IV HISTORIA MODERNA

REVISTA DE LA FACULTAD DE GEOGRAFÍA E HISTORIA

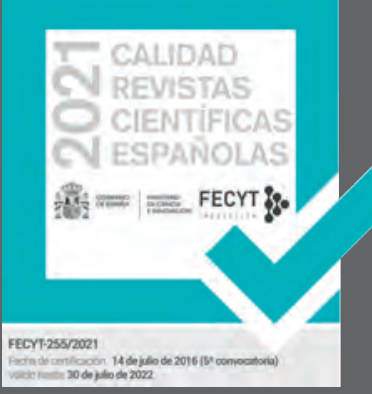




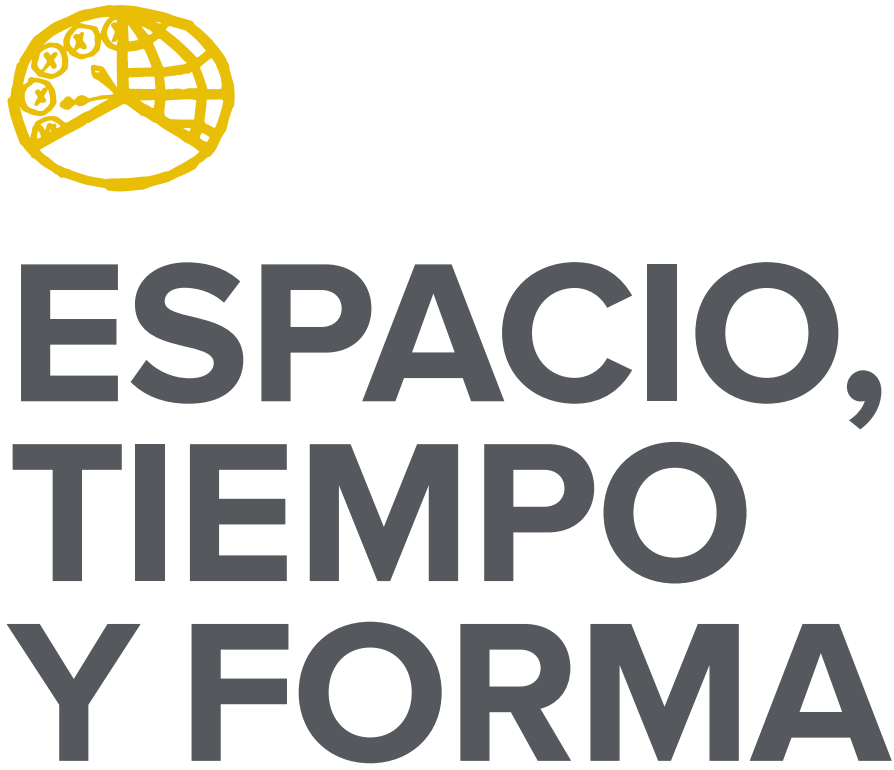

AÑO 2021

ISSN 1131-768X

E-ISSN 2340-1400

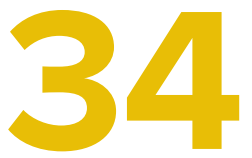

SERIE IV HISTORIA MODERNA

REVISTA DE LA FACULTAD DE GEOGRAFÍA E HISTORIA

DOI: https://doi.org/10.5944/etfiv.34.2021

\section{UกED}

UNIVERSIDAD NACIONAL DE EDUCACIÓN A DISTANCIA 
La revista Espacio, Tiempo y Forma (siglas recomendadas: ETF), de la Facultad de Geografía e Historia de la UNED, que inició su publicación el año 1988, está organizada de la siguiente forma:

$$
\begin{aligned}
& \text { SERIE I - Prehistoria y Arqueología } \\
& \text { SERIE II - Historia Antigua } \\
& \text { SERIE III - Historia Medieval } \\
& \text { SERIE IV - Historia Moderna } \\
& \text { SERIE V - Historia Contemporánea } \\
& \text { SERIE VI - Geografía } \\
& \text { SERIE VII - Historia del Arte }
\end{aligned}
$$

Excepcionalmente, algunos volúmenes del año 1988 atienden a la siguiente numeración:

$$
\begin{aligned}
& \mathrm{N} .^{\circ} 1 \text { - Historia Contemporánea } \\
& \mathrm{N}^{\circ} 2 \text { - Historia del Arte } \\
& \mathrm{N} .^{\circ} 3 \text { - Geografía } \\
& \mathrm{N} .^{\circ} 4 \text { - Historia Moderna }
\end{aligned}
$$

ETF no se solidariza necesariamente con las opiniones expresadas por los autores.

\author{
UNIVERSIDAD NACIONAL DE EDUCACIÓN A DISTANCIA \\ Madrid, 2021 \\ SERIE IV · HISTORIA MODERNA N. ${ }^{\circ} 34,2021$ \\ ISSN $1131-768 X \cdot$ E-ISSN 2340-1400 \\ DEPÓSITO LEGAL \\ M-21.037-1988 \\ URL \\ ETF IV · HISTORIA MODERNA · http://revistas.uned.es/index.php/ETFIV \\ DISEÑO Y COMPOSICIÓN \\ Carmen Chincoa Gallardo · http://www.laurisilva.net/cch \\ Impreso en España · Printed in Spain
}

(c) (7) (8) Esta obra está bajo una licencia Creative Commons Reconocimiento-NoComercial 4.0 Internacional. 


\section{MONOGRÁFICO · SPECIAL ISSUE}

LA POLÍTICA ULTRAMARINA DE LAS MONARQUÍAS

IBÉRICAS (CIRCA 1700-1750): UNA HISTORIA

DE FRACASOS Y ÉXITOS RELATIVOS

THE OVERSEAS POLICY OF THE IBERIAN MONARCHIES (CIRCA 1700-1750): A HISTORY OF FAILURES AND RELATIVE SUCCESSES 



\title{
PORTUGUESE AMERICA UNDER FOREIGN THREAT AND THE CREATION OF THE CONCEPT OF UTI POSSIDETIS IN THE FIRST HALF OF THE 18TH CENTURY
}

\section{LA AMÉRICA PORTUGUESA BAJO LA AMENAZA EXTERIOR Y LA CREACIÓN DEL CONCEPTO DE UTI POSSIDETIS EN LA PRIMERA MITAD DEL SIGLO XVIII}

Junia Ferreira Furtado

Recibido: 15/12/2020 - Aceptado: 22/04/2021

DOI: https://doi.org/10.5944/etfiv.34.2021.29359

\begin{abstract}
$^{2}$
The aim of this article is to discuss the relationship between invasions, cartography, and possessory law in the context of diplomatic relations between Portugal and Spain in the first half of the eighteenth century, in South America territories. The Castilian siege of Colônia do Sacramento and the French invasion of Fernando de Noronha island (1736 and I737), awoke in the Portuguese ambassador D. Luís da Cunha the need to change the foundation on which the frontiers of Brazil were negotiated. He began to use the concept of uti possidetis as a strategy, which would become the directive for the diplomatic negotiations in the 1750 Treaty of Madrid. Despite its acceptance as a resource to demarcate frontiers, uti possidetis created various controversies at the moment of the demarcation of the territories and the Treaty was annulled by the Treaty of El Pardo (I76I), when the legal frontiers returned to their previous positions.
\end{abstract}

Keywords

Uti possidetis, Diplomacy, Brazil, Treaty of Madrid, Luís da Cunha

\section{Resumen}

El objetivo de este artículo será la discusión en torno a la relación existente entre las invasiones militares, la cartografía y el derecho posesorio en el contexto de las relaciones diplomáticas hispano-portuguesas durante la primera mitad del siglo XVIII. El asedio castellano de la Colonia del Sacramento y la invasión francesa de la

\footnotetext{
1. Universidade Federal de Minas Gerais; juniaff@gmail.com

2. I would thank CNPq, CAPES and Fapemig for funding this research.

Abbreviations: Archivo do Itamaraty (Al, Itamaraty), Arquivo Nacional da Torre do Tombo (ANTT, Lisboa), Arquivo da Universidade de Coimbra (AUC, Coimbra), Biblioteca da Ajuda (BA, Lisboa), Biblioteca da Academia das
} 
isla de Fernando de Noronha (I736 y 1737) despertaron en el embajador portugués D. Luís da Cunha la necesidad de cambiar los fundamentos sobre los que se negociaban las fronteras de Brasil. Comenzó a utilizar el concepto uti possidetis como estrategia en las negociaciones sobre los territórios. Apesar de ser aceptado en el Tratado de Madrid de I750 para demarcar las fronteras, el uti possidetis creó controversias en el momento de la demarcación de los territorios y el Tratado fue anulado por el Tratado de El Pardo (176I), e las fronteras legales volvieron a sus posiciones anteriores.

Palabras clave

Uti possidetis, diplomacia, Brasil, tratado de Madrid, Luís da Cunha 


\section{INTRODUCTION}

In his monumental work on the Treaty of Madrid, signed by Portugal and Spain in I750 and which governed their borders in the Americas, Jaime Cortesão stated that it was necessary «to seek a legal foundation, prior to the Treaty of Tordesillas, capable of surpassing it in prestige», and that it was Alexandre de Gusmão who «found in Uti possidetis in Roman law the conservative form of sanctioning a new and revolutionary principle of law between peoples» ${ }^{3}$. Much more recently, Synesio Goes Filho made the same assertion and wrote that it was the «Brazilian Alexandre de Gusmão, at the time Private Secretary of D. João V», who formulated in the Treaty of Madrid its two structural principles: «that of 'natural frontiers', such as river courses and mountain ridges, and uti possidetis, which determines that each party keeps the land it occupies»4.

This premise was based on the text of the Primeira Minuta do Tratado (First Draft of the Treaty), sent from Portugal in September I748. This was the first official Portuguese document to determine that demarcation would «use as its first basis the determination of preserving as much as possible, and where this does not offer significant inconveniences to the contrary, current possession and occupation, and choosing everywhere, insofar as the situation allows this, the natural divides of mountains and rivers». Although the document was sent by the Secretary of Foreign Affairs, Marco António de Azeredo Coutinho, the two historians believed that its real author and the artificer of all the negotiations had been Alexandre de Gusmão. Cortesão justified this assertion because he had found a copy of a letter forwarding the draft and another of the latter in the «handwriting of Gusmão, with the signature of the Secretary of State» 5 . In other words, he believed that Coutinho was not the real author and that Gusmão was not a mere secretary, but rather the person who actually produced it. Another letter, dated I6 May I749, in which the Secretary stated that since the return to diplomatic negotiations Portugal had adopted «as preliminary maxims, in first place that in the lands already occupied by any of the parties, each would keep what they had occupied», highlighting the importance of jus possidetis as a strategic pillar, also had a copy in Gusmão's handwriting and signed by Coutinho ${ }^{6}$, which reinforced, according to Cortesão, Gusmão's authorship of the introduction of this diplomatic novelty. Cortesão believed that Gusmão «found in Uti possidetis from Roman law a conservative form of sanctioning a new and revolutionary principle of the law of peoples» 7 .

The use of de facto occupation as a mechanism to guide the drawing of the frontiers of South America was presented by the Portuguese to the Spanish shortly after the negotiations began in Madrid. It was on 9 July I747, during the first meetings with Dom José de Carvajal, Spanish Secretary of Foreign Affairs, that the

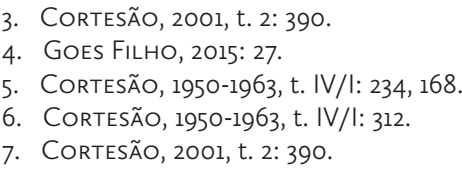


Portuguese ambassador, Viscount Cerveira, verbalized for the first time the concept of uti possidetis, though without naming it. Questioned by the former about the difficulties involved in defining frontiers in the Americas, he proposed that the new treaty be very succinct «and that the main part would be to give ownership to what each had». Cautiously, the Castilian promised him «to put this clause at the end of the memorial [which he had written about the Castilian position], in the case that if it could not be put into execution the terms would be adjusted a quo to remove the dividing line» ${ }^{8}$.

It was undoubtedly a mechanism that was clearly favorable to the interests of the Portuguese, as can be seen in the text of the Primeira Minuta, which listed only usurpations on the Luso-Brazilian side: the third article stipulated that in the north belonging to the «Crown of Portugal [would be] everything it had occupied above the Amazon and in the sertão on both sides [...], as well as what it had occupied in the districts of Cuiabá and Mato Grosso, irrespective of any claim of the Spanish Crown due to the Treaty of Tordesillas». According to the sixth article, Spain would cede in the south the territory that «was occupied [by the Portuguese] from the northern bank sertão of the Rio Negro» to the «eastern sertão of the Uruguay River», rivers which would serve, together with the Pequiri, as fronteirs between the two nations, with navigation along them being shared..$^{10}$ On the whole, the Portuguese proposal was guided by the concept of uti possidetis, pushing the borders of Brazil as far to the West as possible, preserving for example, «the eastern bank of the same wetlands, which [were] frequented 'by our Paulistas ${ }^{\text {II }}$ who travelled by water to Cuiabá and similarly both ways along the Jaurú, which flowed into the Paraguay River and which served as the route from Cuiabá to Matogrosso»; the bed of the Madeira River, which the Paulistas went up by canoe until they reached the Mamoré; the «bank and western sertão [of the Rio Negro, where] we have many villages and establishments»; and the Japurá River, along whose banks the residents of the province of Pará had their principal harvest of cacao. Only as a secondary method did the Minuta allow «that it would be sought to form the divide along the most conspicuous and notable landmarks of mountains or large rivers $»^{\mathrm{I} 2}$. When he gave the plan to Carvajal, Cerveira assured the authorities in Portugal that in the negotiations, «the path I have taken is to always base myself on preserving what we possess in America» ${ }^{13}$. In other words, he was guided by uti possidetis.

Documents passed to-and-from between the parties and on 7 September I748, Cerveira made his second comment on the second memorial he had presented to the Spanish, where he listed the main points defended by the Portuguese which had to appear in the treaty. Afterwards Alexandre de Gusmão made his observations on the two documents and listed eight principal guidelines which Cerveira

8. CORTESÃo, 2001, t. 2: 282 .

9. Sertão meaning the unknown interior land.

10. CORTESÃo, 2001, t. 2: 320-325 (emphasis added).

11. Paulistas were the people from São Paulo captaincy. Several of them organized and participated in exploring expeditions sent to the interior sertões, which was why they were named sertanistas.

12. CORTESÃO, 1950-1963, t. IV/I: 312.

13. CORTESÃO, 2001, t. 2: 324 . 
should follow in the negotiations. As a third point he argued that it was «preferable for Spain to compensate some occupied areas with others», referring to territory beyond the Tordesillas line which the Spanish held in the Pacific Ocean, and that «current possession would continue to serve as legitimate, fixed, and unalterable title of ownership of both parties ${ }^{14}$. The text of this document reiterates the use of uti possidetis as the main mechanism for the definition of territories between the two parties. Furthermore, attributed by Cortesão as being written by Gusmão, this is the first document that he drafted by himself in which the concept appears in writing, when the negotiations were already well advanced.

However, while since the Primeira Minuta of 1748 the preliminary maximum proposed by the Portuguese to regulate the limits was uti possidetis, followed by the natural divisions of the terrain, advocated by Spanish authorities, in the final text of the Treaty of Madrid their precedence and hierarch was inverted, which constituted a victory for Carvajal ${ }^{15}$. In its Preamble, in first place it was established that in lands that were known the natural divisions of the terrain would be used and, as a second resource, it was determined «that each party has to keep what it currently possesses, with the exception of mutual cessions $»^{16}$.

This article does not discuss the prominence (or not) of Alexandre de Gusmão in the preliminary negotiations or in the 1750 Treaty of Madrid, however, various documents analyzed here reveal that the Secretary of State, Marco António de Azeredo Coutinho, was not a mere passive agent ${ }^{17}$. What it is thus intended to reveal is that he was not the first to formulate the idea of uti possidetis as a strategy to negotiate the frontiers of Brazil, nor the person responsible for the introduction of this concept in the discussion in Madrid, rather it was the Portuguese ambassador Dom Luís da Cunha, on this occasion serving in Paris ${ }^{18}$.

Dom Luís da Cunha was one of the most important Portuguese ambassadors in the first half of the eighteenth century, serving in various European courts and as the diplomatic representative of Portugal in the principal treaties negotiated during this period which, among other important questions, dealt with the frontiers of Brazil ${ }^{19}$. How did his ideas on the concept of uti possidetis emerge? We will examine how the ambassador defended the way the negotiations of these territorial borders should be carried out, which led him to develop the notion of uti possidetis. This effectively became the main line of diplomatic negotiation used by the Portuguese with the Spanish in and after I750. We also demonstrate he influenced the negotiations in Madrid and its failure in the Treaty of El Pardo.

4. CORTESÃO, 2001, t. 2: 300; CORTESÃO, 1950-1963, t. IV/I: 173.

15. CORTESÃO, 1950-1963, t. IV/I: 312; CORTESÃO, 2001, t. 2: 375.

16. CORTESÃO, 2001, t. 2: 365 .

17. Coutinho had served in Portuguese embassies with Dom Luís da Cunha. He was an admirer of the latter and discussed the Portuguese negotiation strategies intensely with him. Not by chance, when Coutinho was chosen as Secretary of State, Dom Luís addressed the Instruções Políticas to him, since he considered himself an oracle of Portuguese geo-politics. FurTADO, 2012: 40-49, 131-133; SILVA, 2001 .

18. Furtado, 2012: 276-300.

19. Cluny, 1999; Silva, 2001; Furtado, 2012: Furtado, 2013. 


\section{THE CAPTAINCY OF MINAS GERAIS AND THE IMPORTANCE OF BRAZIL IN THE PORTUGUESE EMPIRE}

The idea of the centrality of Brazil developed in Dom Luís' mind as he gradually became aware of the growing importance of products originating from overseas conquest in the empire's economy, overshadowing the Far East ${ }^{20}$. Looked at from a geopolitical perspective, sugar and tobacco were seen as currencies for trade with other European economies. Among the many goods, gold and later diamonds were of special importance, and because of this the ambassador began to attribute immense importance to the Minas region as it was the location of that wealth. In I7I9 he wrote to his old friend, the $2^{\text {nd }}$ Count of Assumar, and in his irreverent style declared «that Brazil [and] those Mines [Minas] are the Old Lady's goods $»^{21}$. By Old Lady he was referring to Portugal.

Dom Luís da Cunha called attention not only to an economic reorientation of the Portuguese empire, but also in its political position. Throughout his correspondence, and in particular in his renowned Instruções politicas, he clearly stressed the importance of the discovery of gold and diamonds in the captaincy of Minas Gerais, highlighting Portugal's increasing economic dependence on Brazil. As a corollary of this dependence, he advocated that «the prince, in order to maintain Portugal, is completely dependent on Brazil's wealth, and not at all on Portugal's [...] from which one might conclude that it is more comfortable, and safer, to be where one has what abounds, [than] where one desires what is lacking». That is why he defended the need to transfer the court to the Americas, establishing it in Rio de Janeiro from where the king would govern, assuming the title of «Emperor of the West» $»^{22}$.

At first, Dom Luís, like other members of the Portuguese elite, was skeptical of the importance and duration of the discoveries, but he soon concluded that «the conquests, which I had believed to be an accessory for Portugal, I now consider to be its main asset, and even guarantees its conservation, especially those of

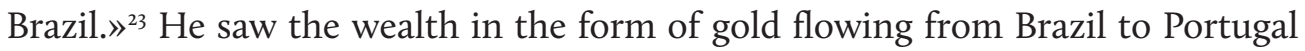
as a possibility which could compensate for Portugal's small geographical size and its meager economic resources. For that reason, according to his principles, it was important that gold did not continue to fill the coffers of other European nations, especially England. The awareness of the growing importance of Portuguese gold in the European monetary circuit, which increasingly fueled the development of the economies of England, France, and the Netherlands, made the ambassador recognize the importance of Brazilian mines in this process. However, more than this was involved. He became increasingly aware of the interest they aroused in Europe and the threat that interest represented to Portugal's maritime empire, «since those dominions' riches are today the envy of all nations». He then began

\footnotetext{
20. Silva, 2001a: 60; Silva, 2001b; Furtado, 2010: 373-400; Furtado, 2013: 286-327; FurTado, 2014.

21. «O bem que a Velha tem». Al, Cartas oficiais de Dom Luís da Cunha, 1719-1723, f. 41, Madrid, May 1719.

22. CUNHA, 2001: 371

23. CUNHA, 2001: 279
} 
continuously calling the attention of Portugal's authorities to the urgent need to protect them from the envy of foreign powers. This can be seen in some of his many observations: «The security of the Americas is necessary because the wealth of our Mines makes increasingly more noise and causes greater envy» ${ }^{24}$ and «With as much of a stir as the wealth of our mines naturally makes in the world today, it is understandable that it triggers the ambition of [foreign] men of business to seek all means of acquiring part of that great profit $\aleph^{25}$.

At the end of I730, after the arrival of many fleets loaded with gold and diamonds, he had no more doubts about the centrality and importance of the region for the enrichment of the empire, a vision that culminated in his controversial proposal to transfer the court to Brazil, contained in his Instruções Políticas, which he began to write around I736. When Jean-Baptiste Garnier de Fougeray, head of the French Compagnie des Indes, offered to go discover the South Sea in the name of the Portuguese «or any others yet unknown», Dom Luís da Cunha does not express much enthusiasm for the project. He justified his decision saying that it was «because we had and have in Brazil so much to discover and with less risk and expense and with more benefit $»^{26}$.

In I7IO and I7II the French invasion of Rio de Janeiro and the danger the latter posed for Portugal's hold on Brazil made a strong impression on him. He feared the possible combination of an external threat and an internal uprising, as he had been made aware that there was a revolt underway in Minas - this was in reference to the disturbances resulting from the War of the Emboabas, when Paulistas ${ }^{27}$ and recently arrived Portuguese vied for control over the mining region. Internal dissatisfaction could become unmanageable if it coincided with an external invasion motivated by foreign powers' lust for Brazilian gold ${ }^{28}$.

In I712, he was informed of an English expedition, commanded by a certain Captain Thomas Blau, that planned «to establish a new colony, which, although it is still unknown where it will be attempted, suffices to be in the vicinity of Brazil to cause us unparalleled damage». He speculated that «if it was in Santa Catarina Island or Ilha dos Patos, we can be certain that we would lose a significant profit from the mines, as the English would usurp most of that trade». The argument was of the transitivity of the possession of strategic locations on the coast as a way to ensure control over Minas, which was the key piece among the Portuguese possessions ${ }^{29}$.

In the early I720s Dom Luís was again assailed by the same fears that preoccupied him a decade before. Once again, troubling news was arriving from Minas, and he was preoccupied with the combination of a Foreign invasion and a new disturbance

24. ANTT, Ministério dos Negócios Estrangeiros, livro 790, f. 270, Paris, Sep. 8, 1721.

25. ANTT, Ministério dos Negócios Estrangeiros, livro 783, f. 499, London, Dec. 3, 1709.

26. CUNHA, 2001a: 343

27. The Paulistas had discovered the gold mines with their expeditions into the interior. They claimed that for this reason they had the right to administer the area and viewed the newly arrived Portuguese as invaders. They nicknamed the latter Emboabas, which meant chickens wearing trousers, a reference to their long boots.

28. ANTT, Ministério dos Negócios Estrangeiros, livro 786, f. 403, Paris, Sep. 2, 1712.

29. ANTT, Ministério dos Negócios Estrangeiros, livro 786, f. 403, Paris, Sep. 2, 1712. 
in the Brazilian mining region ${ }^{30}$. Due to the avarice of the British and warned about another possible expedition organized by them to invade Brazilian territory and seize the gold mines, Dom Luís da Cunha sought out the English representative. The latter assured him that «England's interests were not to discover gold mines that far away when they found gold and silver in Portugal, without the dangers of navigating through so much ocean or the troubles of digging up so much earth». Dom Luís' fears were not assuaged but he concluded that it was true that the British would not go to the trouble of dealing with the political consequences of such an invasion, since «the opinion the English have of us [...] is of the profit they derive from our trade» ${ }^{3 \mathrm{~T}}$.

\section{COLÔNIA DO SACRAMENTO}

Colônia do Sacramento was established in I68o by a Portuguese expedition commanded by Dom Manoel Lobo, then governor of Rio de Janeiro. At the time, five ships landed there with about 440 people, with the purpose of creating a settlement. The first Portuguese enclave situated on the River Plate, on its northern bank opposite to Buenos Aires, was Colônia do Sacramento, which was of vital interest to the crown, since it was a strategic location for Portugal to take advantage of the contraband trade of the silver exploited by the Spanish in the Andean region. Its immediate purpose was to facilitate access to Portuguese merchants, especially from Rio de Janeiro, to trade with Spanish possessions, where payment was made in silver. Its foundation provoked an immediate reaction from Spain, and a few months after its foundation Colônia do Sacramento was invaded and destroyed by an expedition sent by the governor of Buenos Aires. In I68I, through the Provisional Treaty signed by Portugal and Spain, the territory of Colônia do Sacramento was returned to the Portuguese, who sent a new expedition to restore the fort and repopulate it. In I705, in the context of the War of Spanish Succession, Spain once again drove out the Portuguese troops stationed there. The negotiations between Portugal and Spain at the Congress of Utrecht, when Dom Luís da Cunha was one of the Portuguese diplomats, with the English as mediators, were costly and lengthy. A second restitution of Colonia do Sacramento to Portugal was then agreed in the Treaty of Utrecht, finally signed between Portugal and Spain on February 6, $1715^{32}$.

The expression al presente la tiene (currently possesses) stipulated in the Provisional Treaty had given rise to many controversies during the negotiations

30. He was referring to «the altercation that occurred in Vila Rica at the mines of Ouro Preto, where some dissenters made the people rebel against the judge of that jurisdiction, who left, and then the uprising continued with the pretext of the mints and foundry that were about to be established for the payment of the royal taxes, and it lasted some days, and the governor, the Count of Assumar attempted to subdue it by yielding to some of the proposals they had made», known as Vila Rica's Rebellion. ANTT, Ministério dos Negócios Estrangeiros, caixa 816, Nov. 5, 1720 .

31. ANTT, Ministério dos Negócios Estrangeiros, livro 790, ff. 97-98, Paris, Apr. 7, 1721.

32. Almeida, 1957; Possamal, 2006; Furtado, 2012: 263-276; Martín Marcos, 2012: 151-175; Furtado, 2013: 312-327. 
in Utrecht. After all, what lands did the Portuguese occupy in I680-I? The lack of adequate maps hindered them from establishing a text that more precisely determined the boundaries negotiated and forced Portuguese diplomats to create a new expression - Colônia do Sacramento and its Territory - which was written into the Treaty of Utrecht. What had seemed to be an astute political move the inclusion of the word «Territory»-soon became a nightmare. The Spanish insisted that the term «Territory», in capitals, inserted into the accord by the two ambassadors corresponded only to the countryside around the fort, and stubbornly refused to restitute more than the territory within the range of a cannonball, which corresponded to about three kilometers around the fort, while to the Portuguese it comprised all the Northern bank of the river.

Since i7ios Dom Luís da Cunha established a connection between Colônia do Sacramento and the possession of Minas, proposing an increasingly assertive policy of the settlement and defense of the south of Brazil. He had already given a similar advice in I7I2, when he was informed of the English Blau expedition which planned to invade the south of Brazil. To prevent this, he suggested that Portugal «should immediately send, without delay, orders to Brazil to dispatch a ship to the islands of Santa Catarina and dos Patos with people taking some cabins, which would suffice to prove that we have possession over them». Effective colonization would be the strongest counterpoint to legally neutralize possible English colonization, since «in these terms other powers will not refrain from helping us uphold an unquestionable right». He concluded: «The same should be done in any other port on the coast of Brazil from the Amazon River to the River Plate, because it is a very inexpensive precaution that prevents many issues that could be inflicted upon us by the avarice of others awakened by the wealth of our Mines» ${ }^{33}$. Early in I7I4, he proposed some solutions to protect the Brazilian mines that could sometimes be «of little cost [and] would free us from many issues that could result from the avarice of others that the wealth of our mines is awakening.» He was referring to protecting the coast of Brazil, encouraging the settlement of strategic areas such as Santa Catarina Island and various ports located between the mouth of the Amazon and the River Plate. If at that time he still wondered «whether the wealth of our mines...is greater in reputation than in effect» ${ }^{34}$.

The governor of Colônia do Sacramento between 1722 and I749, Antônio Pedro de Vasconcelos, echoing the geopolitics of Dom Luís da Cunha, stated that the Treaty of Madrid opened to Spain «the door to what until now was the key to our Colônia» and allowed the Castilians to reach «the road which runs directly to the sertão of that hidden country,» whose roads were «necessary to the traffic of Minas Gerais.» According to him, surrendering Colônia would hand over «the key to our Minas.» ${ }^{35}$

In late I735, after a diplomatic incident in the Portuguese embassy in Madrid, the Spanish imposed a severe blockade on Colônia do Sacramento. This episode

33. ANTT, Ministério dos Negócios Estrangeiros, livro 786, f. 403, Paris, Sep. 2, 1712.

34. ANTT, Ministério dos Negócios Estrangeiros, caixa 926, f. 56, Jun. 21, 1714.

35. CORTESÃO, 2001, 2: 386-387. 
was called the Great Siege and «for almost two years [1735-I737] it brought the residents of Colônia do Sacramento close to starvation ${ }^{36}$. Spain's audacity and the danger that the siege represented to Portugal's plans for the River Plate basin led Dom Luís da Cunha to give up the almost always peaceable tone of his recommendations to the crown. In July I736, he asked Portugal's authorities what would be their strategy to retaliate against Spain's military offensive: whether «to pay no heed to the mediators' proposals as long as the Colony is not restored, in case it is invaded, or to engage in negotiations [and] send to the River Plate whatever forces there are in Brazil to recover it and in addition attack Buenos Aires if possible». He complained that the planned fort of Montevideo never left the drawing board but argued that there was still time to build it, «for we will keep it while the dispute continues regarding how far the territory of Colonia do Sacramento will extend toward the Uruguay River; and if perchance an equivalent in Europe is discussed, the more we have to give up, the better» ${ }^{37}$. In fact, after Dom Luís advice, as we will see, in 1736 the Portuguese began a period of more aggressive systematic occupation of southern Brazil, with the construction of forts (Jesus Maria José in I737) in Rio Grande de São Pedro and the arrival of migrants from Azores to Santa Catarina (I740), ${ }^{38}$ the same proposal he had suggested in I7I4.

The use of colonization to guarantee the defense and possession of a territory as a diplomatic expedient in the frontier negotiations would be gradually constructed in his thought, based on the conjugation between foreign threats to Brazilian territory, which became real around I736-I740, and the need to guarantee the mining areas. In this period the possession of Colônia do Sacramento was threatened, new foreign attacks on Brazilian territory occurred, at the same time as new discoveries of gold and diamond occurred ever more to the west, advancing over territory to which Spain had a right, the case of the mines of Goiás and Mato Grosso ${ }^{39}$.

He then began to argue that the issue of defining the frontiers with Spain should be addressed as a whole, considering not only all of South America, but also the region of the Maluku Islands in the South Sea (Pacific). Portugal's invasion of territories in the middle of the Americas and the purchase in 1529, through the Treaty of Zaragoza, of the Maluku Islands from Spain - a territory to which Portugal already had a right according to the Treaty of Tordesillas - in addition to the inaccuracy in the location of that meridian, required, in his opinion, the establishment of new and more precise boundaries. His work in the treaties of Utrecht and Cambrai and in the main European courts convinced the ambassador that any negotiation with Spain would not be limited to borders in Europe but would necessarily encompass an entire geopolitical reorientation of the boundaries between the two crowns in the Americas and the Pacific. He was aware of the role that Brazil had come to occupy in the Portuguese empire, and that it was necessary to include as much territory as possible in the mid-western and Amazon regions,

36. PRADO, 2002: 119 .

37. AUC, Cartório de Dom Luís da Cunha, doc. 359, Aug. 17, 1736

38. RODRIGUES, 2014: 131-155.

39. Furtado, 2012: 381-434; FurTAdo, 2013: 222-229; FurTAdo, 2016: 367-399. 
while maintaining a certain security in the south. He then began insistently arguing that Portugal's greatest wealth at that moment was located in Minas Gerais, and that the region of Colônia do Sacramento, at the mouth of the River Plate, given its complete lack of economic interest, would be the key bargaining chip with Spain during the negotiations. The unjust purchase of the Maluku Islands could also be called on to ensure the possession of Colônia do Sacramento if necessary. Regarding the Amazon region, he believed that what was essential for Portugal was to keep control over both banks of the Amazon River, thus guaranteeing the monopoly of its navigation.

\section{UTI POSSIDETIS}

As a result of the disputes about Portugal's sovereignty over the region of Colonia do Sacramento and his preoccupation with maintaining control over gold production in Minas Gerais, Dom Luís da Cunha began to connect some of the issues that would become cornerstones in his thinking on how negotiations with Spain should be managed: the use of natural landmarks to establish frontiers, respect for previous treaties, and the idea of uti possidetis, in other words, to «consider valid the possessions each one currently has» ${ }^{40}$. We will examine only the latter here, considering that it was not by chance that these three premises first appeared as a whole in arguments in favor of Portugal's territorial interests in the Americas in the Treaty of Madrid of I750, clearly as a result of the influence of the geopolitical thinking outlined by the ambassador in the elaboration of Portugal's negotiation strategies ${ }^{41}$.

As Isabel Cluny points out, the issue of the definition of borders is directly related to the issue of the exercise of sovereignty by Ancien Régime's monarchies during the Modern era $^{42}$. In fact, «almost all monarchies of Western Europe began an intense process of incorporating territories (through inheritance, conquest, or agreement)»43. During the eighteenth century, these European powers made an extensive use of war (jus belli) and agreements (jus tractum) negotiated through diplomatic means (jus legations) to obtain territories and enlarge their borders, both in European soil and overseas. Invoking the concept of jus de facto, reviving that of Roman uti possidetis, establishing a transitivity between the right of possession and that of actual colonization, superimposed on the right of conquest - jus belli - and what was negotiated in diplomatic accords - jus tractum - was the strategy which Dom Luís prepared in a progressive manner from the I7Ios onwards.

However, after the Congress of Utrecht, «the temptation to expand borders through war was increasingly restrained by international necessities expressed in the theory of the balance of powers and recognized for the first time at the congress» ${ }^{44}$.

40. CORTESÃO, 1950-1963, t. IV/1: 92-93.

41. FERREIRA, 2001: 46-47.

42. CLUNY, 1999: 99-102.

43. CARDIM, 2008: 362 .

44. Cluny, 1999: 100. 
This emphasis on negotiation as a means to ensure dominion/sovereignty over territories demanded new legal approaches and diplomatic tactics to provide a foundation for the claims of crowns in constant disputes over territories. We can thus see in Dom Luís da Cunha's writings how he gradually began to draft his strategies to address and justify Portugal's claims, which, while not set down in the form of a treatise, were internally coherent and articulated a system of thought that conjugated the three premises mentioned in the previous paragraph.

In the Eighteenth-Century South America was one of the great stages outside of Europe of territorial conflicts between European nations, demanding the definition of borders that were systematically negotiated in the various treaties enacted throughout the century. For Portugal, and for Dom Luís in particular, it was not only a matter of negotiating Brazil's limits, but of understanding that «Brazil functions as Portugal's frontier». In other words, Portuguese America, replacing the Far East, gradually emerged as a natural reserve of wealth for Portugal, which justified the effort to displace its own external frontier to regions increasingly more distant from the coast, taking as the crown's dominions territories that in theory, according to previous treaties, belonged to other nations or were understood as uninhabited, as terra incognita, still waiting to be colonized. «Brazil can therefore be seen as a frontier society during a long period of its history» ${ }^{45}$, but especially in the eighteenth century. It was that need to negotiate its borders as widely as possible in that century that directed Portugal's cartographic policies toward the Americas, to the detriment of Portugal itself.

The issue of respecting previous treaties developed in Dom Luís' mind in response to the need to legitimize historically acquired or previously negotiated possession rights, even if treaties could seem to contradict other variants such as maps, memoirs, later occupations of land, imaginary demarcation lines. He argued that a new treaty always superseded the previous one, and that the legitimacy of a territorial claim had to be based on the current treaty. Diplomacy was his specialty and negotiating treaties his mission. How could he not believe in the importance of his profession to ensure the maintenance of territories in dispute? Hence the care with which he kept his papers from previous negotiations, his reports of the main events which preserved their memory, such as his Memórias da Paz de Utrecht (Memoir on the Peace of Utrecht), and his adherence in subsequent negotiations to what had been agreed immediately beforehand. However, he was aware of the fact that stronger powers frequently disrespected previous signed agreements, often through the force of arms or the almost silent occupation of a territory that was unoccupied by those who legitimately possessed it.

While history and historical cartography were systematically invoked during negotiations of the territories in dispute, it was the actual colonization of territory which in the final analysis justified the maintenance of its possession and served as an argument to deny the right to the territory to a rival power, even if the latter previously had rights over it. In other words, jus de facto took precedence over

45. Pedreira, 2001: 51, 49 
jus de jure. In I7I4, in the context of the Treaty of Utrecht, aware of the artifice of occupation (uti possidetis) as a guarantor of possession, Dom Luís da Cunha recalled what happened when the Scottish were allowed to colonize the territory of the Gulf of Darien (located on the border between present-day Colombia and Panama). It was requested that the right be extended to all the «lands not possessed by any European power, to [all] uninhabited lands». In other words, uninhabited lands descovered by Spain could not be claimed by European powers, because they had not been previously colonized. They were lands without an owner (excluding native peoples from that right, of course) which could now be claimed by a nation that was only beginning its colonization in the region. Although the Scottish Company was denied that right, because «it was not convenient to England», Dom Luís da Cunha worried about the validity of the argument that a lack of previous colonization by the nation who discovered resulted in the absence of the right of possession, and that an intention to colonize could extend the possession to contiguous areas. Therefore, regarding Brazil, in the context of several foreign invasions, especially French and Spanish, he warned that «it would be good to take precautions with acts of possession of all places still unoccupied that could seem propitious for such settlements» ${ }^{46}$.

It was from this perspective that he began gradually developing the notion of $u t i$ possidetis, the right to the land by those who had occupied and populated the territory, as a complementary element to what had previously been agreed in treaties and, oftentimes, taking precedence over them. He began by expressing this concept more clearly in I736, an ill-fated year as his fears of a possible loss of Portuguese hegemony in Brazil became a reality. Colônia do Sacramento was in danger, surrounded by the Spanish, and the French had invaded Brazilian territory, taking hold of Fernando de Noronha island. Also, in this year there was a new uprising in the captaincy of Minas against a poll tax, something Dom Luís must have been aware of.

\section{FERNANDO DE NORONHA}

In October 1736, while the negotiations regarding Colônia do Sacramento with Spain still dragged on, Dom Luís da Cunha's most dismal predictions seemed about to come true. At that time, he received a letter from Portugal with «the news of the occupation of the island of Fernando de Noronha [which] was confirmed by the news communicated by the viceroy of Bahia, delivered by a ship of ours that landed there» ${ }^{47}$. Reports of the invasion were also sent to Marco António de Azevedo Coutinho:

«Through a ship from the islands coming from Pernambuco, we had the news that the governor of that captaincy, learning that in a nearby island called Fernando de Noronha

46. BNP, Reservados, códice 11.209, ff. 435-435V, Utrecht, Jun. 21, 1714.

47. ANTT, Ministério dos Negócios Estrangeiros, caixa 559, M.E. III-A-Fr-C.2- n. 5, Paris, Nov. 26, 1736. 
some Frenchmen were established who seemed to be pirates, ordered them removed and imprisoned. In the paper Your Excellency will also find the circumstances of this event, which has been communicated to the ambassador Dom Luís da Cunha for him to investigate whether those men are pirates or not, and, depending on his findings, take the necessary actions in that court» ${ }^{8}$.

The ambassador, who was serving in Paris, set his information networks in motion and learned from Mr. de Fugeray, a former captain of the French Indies Company, one of his informants in the government, that a certain «Captain Lesquelin, by order of the (French) Company of the Indies, had disembarked with nine men in the island of Fernando de Noronha». From there, the captain wrote a detailed report informing

«that the island's two ports are good anchorages, that the climate is quite benign, that the land is capable of producing whatever is sowed there, that the goats from which they fed were excellent, that he had already built two fountains and planted several orchards, and in sum providing a detailed list of observations he made regarding the stations, the tides, etc».

While the first reports were not so threatening - there were only eight men - the action's future consequences were quite harmful, since after this «information the Company made the decision to create in that island, which it called Isle Dauphine, a large and useful establishment» ${ }^{49}$. Dom Luís then called attention to the fact that, as part of the act of possession, the French had renamed the island. This act of naming together with the possessory act was part of the whole process of maritime expansion of the Modern Era, with Europeans renaming geographical features as they became aware of them. On his voyage, «Columbus knew perfectly well that the islands already had a name, in a way natural names (but with a different meaning of the term); other people's names, however, do not interest him much, and he wanted to baptize the places in terms of their place in his discoveries... To give them the right names... is equivalent to taking possession $»^{\circ}$.

Dom Luís was worried with the strategic position of the island for Portuguese fleets and because it facilitated illegal smuggling:

«It is unnecessary to tell Your Excellency the consequences of this island remaining in the hands of the French, at only 60 leagues away from the mainland, since Your Excellency is aware of the clandestine trade that in peacetimes they can undertake with Brazil and the trouble they can give us in wartimes with regards to our fleets, which, considering the increasing facilities to make scoops, go to those areas to disembark or whatever else they may need. What I assume is that His Majesty must have promptly requested to know what those people intend to do on an island that belongs to the Portuguese crown ${ }^{51} \gg$.

\footnotetext{
48. ANTT, Ministério dos Negócios Estrangeiros, livro 16, f. 23v, Lisbon, Feb. 22, 1738.

49. AUC, Cartório de Dom Luís da Cunha, doc. 408, Jul. 5, 1737.

50. TODOROV, 1983: 27.

51. AUC, Cartório de Dom Luís da Cunha, doc. 408, Jul. 5, 1737.
} 
But above all he tried to demonstrate that, although there were initially only a few men, they planned «a large and useful establishment», in other words, something more long-lasting, and

«for that purpose [the Company] decided to send onboard the ships, which in September should leave for India, 300 men with all materials and artillery necessary to fortify themselves well, leaving at that port two frigates to better ensure its security. I know that the Company fears that I may have this information and that I may hinder the expedition, yet counting on the fact that once it is done all efforts to make it desist of the undertaking, through either force or negotiation, will be useless ${ }^{52} »$.

He then suggested to the king that, in light of the threat of French colonization, the Portuguese should get ahead of them and effectively colonize the island themselves. This insistence on settling the region was directly linked to the idea of being able to later justify the possession of a territory by the colonization established by a given crown there, extending the right of sovereignty of the monarch to that territory. It was no longer the case of building stone landmarks or crosses, or of claiming first arrival. It was a matter of instituting a society under the aegis of Portugal, of «interiorizing the metropolis» because «the expansion of Iberian monarchies implied the dissemination, at immense distances, of [their] forms of social organization, institutions, and representations» $\$ 3$.

This notion of the right of possession through settlement, which he had expressed for other cases and at other moments, appears clearly in his thought regarding Fernando de Noronha. He stated that the French, after re-baptizing the island Isle Dauphine, planned to build a fortress and leave two frigates there. He suggested to the king that, before more Frenchmen arrived at the island, it was best that «there be a given settlement [there] so it cannot be said that it belongs to no nation, [since] it must belong to the one which takes possession of it and thus renewing ours». He warned that «we are to fear that, upon arrival of the ships with more than three hundred men and supplies, they will enact the possessory act that others have done». These two excerpts illustrate the importance of colonization to renew the possession obtained by the simple primacy of arrival. Revalidating (Portuguese) possession through discovery or the (French) possession through conquest would depend on which of the two nations had the primacy of colonization, creating in the territory a stable settlement. For the second time in his writings he clearly expressed the right of uti possidetis, albeit without naming it.

It is interesting to note that the French geographer Jean Baptiste Bourguignon D’Anville, a long term collaborator with Dom Luís da Cunha and the Portuguese crown, had in his collection a 1737 map by Philippe Buache, entitled Carte de la partie de l'Ocean vers l'équateur, where beside the archipelago of Fernando de Noronha appeared the text: «the island of Fernando de Noronha, named Dauphine in I734

52. AUC, Cartório de Dom Luís da Cunha, doc. 408, Jul. 5, 1737.

53. CARDIM, 2008: 364 . 
by a French navigator» ${ }^{54}$. The map showed the island in detail and, next to the ruin of the old fort, can be seen the wooden cross planted by the French that year. «Naming the island and planting a wooden cross» were performances that were part of the ceremonies with which the French established their possessions in the New World» ${ }^{55}$. Establishing a landmark, renaming a geographical feature, and inserting it in a map under the dominion of another nation were also important forms of possession, especially because maps were very much used as repositories of memory in diplomatic negotiations over rights, anchored in the past, which the different nations had over the disputed territories. On the other hand, the legend of Carte Portuguaise manuscrite de l'Isle de Fernão de Noronha, also in D'Anville's collection, stated: «no. Io - church and settlement made by the French» in the island, but the verb in the past tense suggests the failure of this enterprise ${ }^{56}$. In this context, Isle Dauphine was not a simple curiosity or cartographic aberration. It was a political act of declared possession by France, especially in relation to Portuguese possessions.

It was precisely in I736, in the context of the Spanish siege of Colonia do Sacramento and the invasion of the island of Fernando de Noronha, that Dom Luís da Cunha radically changed his discourse and started to instigate the crown to adopt a more active and openly expansionist policy in southern Brazil. This was a rather different position from the one he had held in I720-I72I, when he feared that such an attitude would provoke further retaliation from Spain. He put aside his policies of relative inaction, since up to that point he had feared Spain's reaction to an increase in Portuguese presence in the northern bank of the River Plate estuary. He then suggested that the king should

I) «send to River Plate the forces we have in Brazil to recover it and in addition attack Buenos Aires if possible» ${ }^{57}$;

2) «in the surrounding waters let us not only displace our enemies, but also build the planned fort of Montevideo, because we will keep it while the extension of the territory of Colônia do Sacramento toward the Uruguay River is disputed; if by chance an equivalent in Europe is discussed, the more we have to give up, the better» ${ }^{8}$;

3) «build [the fort] in Montevideo, settling it 'under the cover of the people and ships sailing from Bahia and Rio de Janeiro' ${ }^{59}$;

4) «begin fortifying and settling the islands that may be apt for it, as for example Santa Catarina, etc., $\rangle^{60}$.

By recommending the fortification of the coast and adopting an aggressive policy of protecting the region, Dom Luís made it clear that, to him, «the concept of frontier was directly related to the defense of the territory and the king's sovereignty against

54. BNF, Department des Plantes et Cartes, GE DD 2987 (9523).

55. SEED, 1999: 63-99.

56. BNF, Department des Plantes et Cartes, GE DD 2987 (9525).

57. AUC, Cartório de Dom Luís da Cunha, doc. 342, Paris, Jul. 20, 1736.

58. AUC, Cartório de Dom Luís da Cunha, doc. 359, Paris, August 17, 1736.

59. AUC, Cartório de Dom Luís da Cunha, doc. 346, Paris, August 24, 1736.

6o. AUC, Cartório de Dom Luís da Cunha, doc. 408, Paris, July 5, 1737. 
foreign powers ${ }^{6 \mathrm{~T}}$.Itissignificantanditcannotbeperceivedasamerecoincidence that in I737, as Dom Luís had suggested the previous year, the Portuguese crown began settling and more effectively colonizing the region of Rio Grande do Sul, building the fort of Jesus, Maria e José. Bringing together his reflections on Colônia do Sacramento and Fernando de Noronha, in August 1736, Dom Luís da Cunha finally clearly outlined the concept of uti possidetis, naming it explicitly. Among the various measures for keeping control of the territory's strategic areas he wrote to the king suggesting that that a fortress be built in Montevideo, settling it «under the cover of people and ships sailing from Bahia and Rio de Janeiro, because it is easier to negotiate when it is done based on uti possidetis than otherwise» Furthermore, he also stated: «an adobe fort is quickly built and with good artillery it is protected, making it a strong garrison ${ }^{62}$.

Since Dom Luís had participated in almost all of the previous negotiations and he had written several reflections on the issue, it was only natural for Gusmão to have access to letters and memoranda from the former, even if they had not been addressed to him. Hence in May I737, Gusmão received «Dom Luís da Cunha's papers and letters that arrived by mail and that Milord Tirawley received, and with a memoir attached, [...] so that in His Majesty's service Your Highness may read them and make all the reflections necessary in accordance to the gravity of this matter ${ }^{63}$.

\section{THE WAR OF JENKINS' EAR AND THE ENGLISH THREAT}

Although England was a traditional ally of Portugal, Dom Luís believed that since the reports of the Blau expedition in I7I2 it would be interested in taking over Brazil, due to its wealth in gold and because the establishment in the River Plate region could be promising. In I737, António Guedes Pereira, his secretary in the embassy in Paris, warned the Secretary of State that a certain Mr. Zambone had informed him «that an Englishman and an Italian, who had been in Rio Grande de São Pedro [and] had probed its bar and examined its campanhas ${ }^{64}$, and had proposed to the Court in London that it take possession of this area due to the great use that could be made from this establishment.» He says that the English were not interested in the project, but that the two adventurers offered it to Russia. In exchange, «the Italian had been given a place on the Council of Trade and the Englishman who returned to London where he currently still is, was given the rank of captain, while the Court in Russia resolved to take possession of that place». Afterwards, Pereira described the Russian plans. He also revealed that the English officer had then presented the plan to London merchants who «offered to establish a company, and recently, giving great support to this project, the Duke of Brijoater had resolved to

61. Cluny, 1999: 122.

62. AUC, Cartório de Dom Luís da Cunha, doc. 346, Paris, August 24, 1736.

63. CORTESÃO, 1984, III, 584 .

64. Campanha was the name given to the vast plains covered with grass where cattle could graze in an extensive form, typical of the extreme south of Brazil and Uruguay. 
the same Court to send a ship on [this] mission, Captain Hervor Bogge, with 60 men and a garrison and the Nassau sloop Captain David Burne, who left on 26 April of last year, while the sloop is expected within two months with the intention to take possession of the said place to then send greater forces» ${ }^{65}$.

In I740, this time in the context of the War of Jenkins' Ear involving Spain and Great Britain, the latter sent two expeditions to invade Spain's overseas possessions. One was commanded by Admiral Anson, and it passed by the coast of Brazil. From Paris, Dom Luís da Cunha monitored events. As always, there was uncertainty regarding the results of the enterprise, and it was considered that Portugal could benefit from conflicts between the British-their eternal allies-and Spain. For that reason, the ambassador speculated that

«the uninhabited coast south of the River Plate, which extends up to Magellan's Straits, is not an object [of the expedition] for reasons that are known to all who have read and know of the travels that were made in that region. And passing through that strait to the coasts of Chile is an idea of more work and difficulty than hope. Which led me to conjecture that no more advantageous acquisition could be conceived of here than Buenos Aires, because of the natural advantages of the place as well as the opportunity to navigate the River Plate: whose consequences are far from overlooked here ${ }^{66}{ }^{\prime}$.

Dom Luís believed that England's establishment in the Buenos Aires region would ensure Portugal's possession of Colônia do Sacramento, putting an end to the conflicts with Spain in that matter. However, that would be of little use, since to him maintaining that post was costly and resulted in little or no advantage. On the other hand, the consequences for Portugal's control of the rest of Brazil, especially Minas, which he considered vital for Portugal's enrichment, would be disastrous, because

«if the English become lords of Buenos Aires, they will soon become lords of the River Plate, taking Montevideo, as well as the Paraguay River and the Jesuit missions, from where they will confront the Paulistas, depriving them through their goods of the gold of our Mines, and as a consequence of the trade with our merchants, in addition to turning the ports of Brazil into their entrepôts, where their ships would enter alleging difficulties, or repairs, or provisions, [unless] they find it more convenient to establish themselves on Santa Catarina Island and Ilha Grande to negotiate from there with Rio de Janeiro67》.

It can thus be seen that Portuguese sovereignty over Colônia do Sacramento only made sense if maintaining the right to the gold mines depended on it. To Dom Luís da Cunha, the perception of Brazil's centrality with regard to Minas Gerais, the captaincies of Goiás and Mato Grosso, and the Amazon was part of a

65. ANTT, Ministério dos Negócios Estrangeiros, caixa 560, ME.III-A- Fr..C1.n.102, Paris, Jan. 11, 1737.
66. BNP, Reservados, maço 62, n. 2, doc. 133.

67. BNP, Reservados, maço 62, n. 2. doc. 137, f. 3 v. 
broader geopolitical plan to ensure the sovereignty of the Portuguese empire over the South America.

While the simple invasion of Fernando de Noronha no longer seemed to forecast the loss of Brazil as a whole or of Minas in particular, as he had feared in the I720s, the same could not be said of control over Colônia do Sacramento. Due to its connections to the mining areas in Minas Gerais and the captaincies of Goiás and Mato Grosso captaincies, he continued to warn that «seafaring and trading nations are not engaged in wanting nor can they usurp them, [and] are always studying the ways to take advantage of them, and therefore it behooves us infinitely to hinder them, at least those who trade clandestinely with Brazil» ${ }^{68}$.

\section{THE DISSERTATION}

It is not by chance that around I735 and I736, in this context, Dom Luís da Cunha began collaborating with Alexandre de Gusmão, the secretary and protégé of Dom João $\mathrm{V}$, to write a synthetic document that would serve as the basis for future negotiations, of which Dom Luís was perfectly aware. This summary, which both of them discussed intensely, became known as the Dissertation ${ }^{69}$. In the context of the invasion of Fernando de Noronha Dom Luís da Cunha finally developed the concept of uti possidetis, naming it explicitly, it then moved from his correspondence to the text of the Dissertation, which he had been writing together with Gusmão. In January I735, Dom Luís sent his first comments from Paris and, from a letter to Diogo de Mendonça Corte Real, then Secretary of State, it can be seen that Gusmão was the author, but also that Marco António de Azeredo Coutinho, then working with him in the embassy, was not a mere passive spectator of negotiation strategies, as Cortesão states. In the letter the ambassador says that, «for now, all I can do is to remind Your Excellency to ask the King, our Lord, not to disregard the advice of Count D. Luis [his nephew] and of the author of the Instructions [Alexandre de Gusmão] which came to Marco António who is in charge of this work; I sent it to him straight, accompanied with my regards $»^{70}$.

The document was supposed to synthesize Portugal's view of the differences with Spain over Colônia do Sacramento, summarizing the terms of previous negotiations and expounding the way in which future ones should be guided. Dom Luís da Cunha ${ }^{208}$ corrected and disagreed with some of the positions defended by Gusmão. His corrections and comments would be inserted in the body or placed in the margin of the document. The events of I736, together with all of his previous experience, had a direct impact on Dom Luís' intervention in the process of drafting this document.

As he was used to diplomatic negotiation over land, and as defended by Dom Luís as the principal strategy, Gusmão concentrated on the description of what

68. AUC, Cartório de Dom Luís da Cunha, doc. 408, Paris, July 5, 1737.

69. FERREIRA, 2001: 44 .

70. BA, 51-II-27, f. 10, Paris, Jan. 4, 1735 
had been negotiated between the two parties in the previous treaties. The core of his argument was that although the 1681 Provisional Treaty had granted an exclusive privilege to the Castilians on the northern bank of the River Plate, the I70I Treaty of Alliance revoked the previous treaty and allowed the shared use of this territory by the Portuguese. To prove his argument, he copied some letters from the governors of Buenos Aires, thinking that the Spanish would find it difficult not to belief the testimonies of their own administrators. In these letters, these officials resented the interiorization of the Luso-Brazilians, who took advantage of their campanhas «for cattle drives and to bring from there meat and hides, which they transported downriver in boats» and also complained about the Paulistas, who penetrated peripheral areas to hunt Indians. His aim was to demonstrate the constant presence of Luso-Brazilians on the northern bank of the River Plate, much beyond Colônia do Sacramento. Among them was a letter from D. Manuel Prado Maldonado, governor of Buenos Aires, dated I5 July I700, to the Portuguese governor of Colônia do Sacramento, in which he stated that he had received a report that the Danes intended to invade the River Plate. As a precaution, Sebastião da Veiga Cabral prepared Colônia to defend itself against this possible attack and ordered the region of Montevideo to be garrisoned, another area which would enter the disputes with the Spanish on the southern side of the River Plate ${ }^{71}$. With this, he intended to characterize that the territory contiguous to the fortress, according to the terms established in the Treaty of Utrecht, corresponded to the entire southern bank of the River Plate.

In his commentary on the Dissertation, Dom Luís da Cunha complained about the inclusion that much correspondence «of the governors of Buenos Aires, because it does not demonstrate that we ever had a peaceful possession» of Colônia do Sacramento, «but only a contested one $»^{72}$. In one of his letters addressed to the Secretary of State Azeredo Coutinho, he reiterated this disagreement when he says that, after examining

«the paper that specifies the boundaries that Colônia do Sacramento should have, it is often well made and well thought, and I only think that we should not make use of the letters by the governors of Buenos Aires, because they do not demonstrate that we ever had a peaceful possession, but only a contested one ${ }^{73} \gg$.

His most important contribution to the original text of the Dissertation appeared in the part of the text where Gusmão began to discuss the meaning of the term "Colônia do Sacramento and its Territory», which the Portuguese ambassadors had put into the Treaty of Utrecht. In the margin of the document, Dom Luís added that it is

71. Cortesão, 2001, 2: 33

2. BACL, maço 608A, ff. 149-150.

73. AUC, Cartório de Dom Luís da Cunha, doc. 387, Paris, Nov. 6, 1736. 
«known that the Romans gave the name of Colony, which comes from colonus, to a certain number of people sent to cultivate and settle land they possess or which they intend to get revenue from, so that when His Catholic Majesty [the Spanish king] in the treaties states that he cedes Colônia, it does not mean that he cedes the people who have settled there and use the land, but the lands themselves» ${ }^{74}$.

Two important transformations can be seen here in relation to the mechanisms of frontier negotiations: one semantic and the other judicial. Between the fifteenth century and the beginning of the eighteenth, Portuguese law about its overseas territories was based on the right of conquest, reflected in the titles of kings, each called «Lord of Conquest, Navigation, and Trade». This right, acquired through arms over native peoples, together with that of discovery, and therefore followed by possessory symbols, was what justified overseas possessions rather than colonization, and was invoked in all the Portuguese negotiations with Spain and France involving the frontiers of Brazil, until the Treaty of Madrid. The argument of conquest was invoked along with what had been established in previous treaties, guided by the natural divisions of land to trace the frontier line ${ }^{75}$. Bluteau's dictionary defined in I7I2 conquest as «land conquered» by the «action of conquest» while contemporary political literature justified the dominion of modern European monarchs over their conquered territories, listing the strategies and actions for their maintenance and expansion. A colony was "people who go to some newly discovered, or conquered, land to settle it. The land thus settled is also called a colony» ${ }^{76}$. It can be observed that, according to this definition and the way it was used in European diplomacy in the first half of the eighteenth century, possession of a territory was based on a conquest, an act which, in turn, had to precede the establishment of a colony. The latter was the permanent establishment of settlers, according to the notion of uti possidetis derived from Roman law during the Roman Empire process of expanding colonies.

As can be seen, although Ambassador Sérgio Lima stated that, «Gusmão was responsible for researching in Roman private law the principle of uti possidetis and transplanting it to international public law in the 1750 Treaty of Madrid ${ }^{77}$, Dom Luís da Cunha was actually responsible. Based on the Roman conception that the colonist and the colony were inseparable entities and which, according to Roman law, guaranteed de facto uti possidetis, de hecho according to the Spanish, over a territory, this gained precedence over the right of conquest corresponding to (de derecho) uti possidetis juris, subsequently invoked by Hispanic and HispanicAmerican diplomats, jurists, and historians to justify Spanish rights over their South American territories, «also called the principle of los títulos colonials» ${ }^{8}$. Dom Luís was the inspiration, based on the resignification of Roman law, for the argument

74. CORTESÃO, 1950-1963, III, I: 395.

75. It was neither Gusmão nor Dom Luís da Cunha who introduced the notion of natural divides to guide frontiers. This concept already formed a large part of the justification for the territorial definition process during their period of formation and was invoked diplomatically in treaties such as Utrecht. DION, 1947,

76. BLUTEAU, 1712: 471, 379.

77. LIMA, 2015: 8.

78. GÓES FILHO, 2015: 247. 
that the dominion of the territories disputed by Spain and Portugal on the Brazilian frontiers had to be assured by those who effectively colonized the area. Colonization was thus configured as a judicial condition in itself and the Roman principle of uti possidetis no longer referred to possession based on previous rights, instead becoming based on de facto possession. This leaves it clear why it was contradictory for Dom Luís to present the correspondence of the governors of Buenos Aires, which pointed to shared possession of the territory on the northern bank of the River Plate, in the same document in which he introduced his new judicial argument.

In his Instruções Políticas (ca. I736), aimed at Marco António de Azeredo Coutinho, Dom Luís does not use the term uti possidetis but mentions the colonization strategy as a form of making «the Castilians lose, which must always be our main object». For this the encouragement of migration was suggested, even of Jews and foreigners, since «it is not advisable to depopulate Portugal to populate Brazil». The intention was to settle them on those lands to "penetrate that vast country», cultivating its fields and discovering new mines, including silver. Once they arrived, they were prohibited from returning, «there they would marry, and their children would be very good Portuguese and Roman Catholics», and they could «bear fruit in some part of Brazil, because being so vast, it seems that any canton can be found». This would increase its revenue and expand its frontiers ${ }^{79}$.

After a long discussion, which can be evidence in the various versions of the Dissertation, Alexandre de Gusmão finally consolidated Portugal's position in a document that became known as the Grande Instrução (Great Instructions), dated October I736, addressed to Dom Luís and Azeredo Coutinho to guide the negotiations the first was leading in France, a traditional ally of Spain ${ }^{80}$. The manuscripts of that document were carefully kept by Dom Luís da Cunha during his life ${ }^{8 \mathrm{I}}$. On the northern bank of the River Plate, Gusmão doubted that uti possidetis was the ideal argument to use in the dispute, since the continuous confrontations that took place at the time between Spanish and Portuguese forces in the region made it difficult to predict who would be in possession of what when negotiations took place as the place was at war, invaded by Spanish military forces. Dom Luís da Cunha in turn, had already made by that time uti possidetis the central theme of his arguments along with respect to the negotiation of frontiers in the Americas and he had been arguing with the French that the Portuguese possessions had to return to the prewar position, in other words the entire northwestern bank of the River Plate was assured by the Treaty of Utrecht, since Portuguese law on this territory was never contested, either before or after the Treaty of Utrecht ${ }^{82}$, and was reinforced by de facto uti possidetis.

The text of the Grande Instrução clearly warned Dom Luís that, to the contrary of what he defended,

\footnotetext{
79. CUNHA, 2001: 342-343, 346-347.

80. Cortesão, 1950-1963, t. III/I: 420-454.

81. ANTT, Ministério dos Negócios Estrangeiros, caixa 564, doc. 356, 1756.
}

82. CORTESÃO, 1950-1963, t. III/I: 303. 
«it is not convenient to us to ask that things be restored in status quo, referring to the time before the last hostilities, because it is probable that we have occupied much more; nor to urge until the final decision is made that it be kept in terms of Uti posssidetis, because it is uncertain what we will have kept or lost until the Orders arrive, since Spain has been increasing forces in that part ${ }^{83} \gg$.

In other words, for Gusmão uti possidetis was an occasional strategy, which could be beneficial or harmful to Luso-Brazilian interests, depending on the current context of the Southern Cone. While for Dom Luís da Cunha, as is clear in his comments on the Dissertation text, it was a judicial principle to be used diplomatically in a long term strategy. As can be seen in his interventions in the original text, for him it was not only to be used occasionally in campaigns in an intermittent and shared form, but was a de facto settlement made by 'individuals' who held them as 'possessions', and this was one of the proofs of 'strength' which assured Portuguese dominion over the extensive northern bank of the River Plate, much beyond the Portuguese fortress ${ }^{84}$.

\section{THE TREATY OF MADRID}

On Io July I748, as the negotiations advanced, Viscount Vila Nova de Cerveira, who headed the negotiations in Madrid, wrote to Portugal forwarding and commenting on the letters which Dom Luís da Cunha had sent him from Paris to guide his actions. He stated that he was not aware that the Spanish had intervened to «take possession of everything we occupy from the Maranhão [or Amazon] River to the River Plate», since what it was intended to prevent was the advance of the Portuguese beyond these points, which could threaten the Spanish monopoly of silver reserves. He warned that in this and «in everything else in the opinion of D. Luís da Cunha, I am satisfied with what he says». He guaranteed that he took care to ensure that the articles of the new treaty showed «with greater clarity all the land we occupied and possessed, so that they not only recognize that we legitimately possess them, but that, if by some accident is comes to be understood that they belonged to the Castilians, they will cede them to us» ${ }^{85}$. As can be observed in the comments of the Viscount, Dom Luís insisted that if uti possidetis be used as the principal negotiation mechanism, that the terms of the treaty had to be clear in relation to the Portuguese held territories past the Tordesillas line and for this he insisted that D'Anville's map Amérique méridionale, which he had send to Madrid the previous year, had to be used as the base for the representation of this territory, since it showed the area in question as precisely as possible ${ }^{86}$ and defended that Colônia do Sacramento be used as a means of exchange for mining territories in the Center-West and the Amazon.

\footnotetext{
83. CORTESÃO, 1950-1963, t. III/I: 450.

84. CORTESÃO, 1950-1963, t. III/I: 404.

85. CORTESÃO, 2001, t. 2: 299; CORTESÃO, 1950-1963, t. IV/I: 166.

86. Furtado, 2012; Furtado, 2013.
} 
But it was only in September 1748 that Gusmão first proposed trading the territory of Colônia do Sacramento for an equivalent in land, but he thought this land would be in Europe and not in the Americas. It was therefore not a mechanism to exchange possessions between the two crowns in the New World, nor a question of considering the borders in the Americas as a whole, nor a way of guaranteeing Portugal's possession of large extensions of land, for example, in Amazonia or the center-west. Gusmão wrote to Cerveira that it was better to let the Spanish propose the equivalent they were willing to cede in Europe, advising them that Portugal would consider the proposal, but that it would also be of interest if they also presented a general proposal defining where they considered that the demarcation line should go through. In other words, at that point he let the adversaries take the lead in the negotiations ${ }^{87}$.

Although the tone of Gusmão's discourse changed from that point on, at first, he remained skeptical about whether it would be possible to find an equivalent capable of satisfying both parties. The Spaniards' proposal of advancing toward an exchange, however, resounded in Portugal and the issue started to be seriously discussed, with Gusmão's participation in some of the talks. It was only in the Instructions of November 22, I748 that it was officially decided to cede Colônia do Sacramento to Spain $^{88}$. But in May of the following year, in view of the slowness of negotiations to determine the territories that would be received in exchange, Gusmão asked Vila Nova de Cerveira, «which is, then, the equivalent that His Majesty is offering for the territory of Colônia do Sacramento»? Irritated and skeptical whether the proposal would come to fruition, he challenged the viscount to «glance at the map and you will easily see that we can covet nothing that can be of great value to Spain or of more serious consequences than what we have proposed $»^{89}$. In the end, in the course of negotiations the Portuguese ended up relinquishing Colônia do Sacramento, which became an important bargaining chip, as Dom Luís insistently advocated. It would be handed over to the Spanish in the agreement signed in I750, but not without great repercussions.

Despite Alexandre de Gusmão's initial disagreements, the Treaty of Madrid in great part, due especially to the Portuguese initiative, ended up confirming most of the premises advocated by Dom Luís da Cunha on how the negotiations on boundaries should be conducted. The issue was not limited to Colônia do Sacramento, or only to the Americas, but also included the Maluku Islands, located in the South Sea. Both were the great bargaining chips offered by the Portuguese in exchange for the possessions in the center-west and in the Amazon region. In the latter area, Portugal ensured its dominion of both banks of the Amazon River, and hence the monopoly of its navigation. No equivalent territory was defined in Europe. Territorial borders were established using as guiding principles, first, natural divisions and second uti possidetis, in other words, each power was to keep

\footnotetext{
87. ANTT, Ministério dos Negócios Estrangeiros, caixa 612, Sept. 11, 1748.

88. FERREIRA, 2001: 47.

89. ANTT, Ministério dos Negócios Estrangeiros, caixa 612, May 16, 1749.
} 
the areas it effectively colonized. In this way, the entire sertão of South America passed to the Portuguese.

Under the inspiration of Dom Luís da Cunha, this resignification of uti possidetis appeared in the 1750 Treaty of Madrid. De facto uti possidetis is configured in its Preamble. While in the territories that were known the natural divisions of the land would be used to trace out the frontier, as a second resource it was determined «that each party had to keep what they still possessed, with the exception of mutual ceding of territory» ${ }^{\circ}$. Article XIV stipulated that the dominion of territories disputed by Spain and Portugal on the frontiers of Brazil was to be assured for those who effectively colonized the area. From then on colonization became a judicial condition in itself and the Roman principle of uti possidetis stopped referring to possession based on prior rights, instead becoming based on de facto possession. A reflection of this new meaning attributed to the act of colonization is the fact that, progressively, in the second half of the eighteenth century European overseas possessions were increasingly called colonies, and their antagonism with European metropoles and the relationship between them came to be understood from a perspective of exploitation, which become the key for the movement of independence movements in the Americas.

\section{A GAME OF MIRRORS: THE FAILURE OF THE NEGOTIATIONS}

Aware of the power of maps to guide the negotiations, Dom Luís da Cunha armed himself with cartographic instruments whenever possible to make the territories claimed visible. For him the map thus played the role of the perfect teaching tool in the context of diplomacy and argued that, «although [territorial disputes] will not be decided with geographical maps,» they were useful to make them visible «if we compare them to others and we are prepared for any argument that may arise» ${ }^{91}$.

During the years preceding the signing of the Treaty of Madrid, following the arrival of Vila Nova de Cerveira in that city in 1746 , maps came and went between Lisbon, Madrid, and Paris, «to inform the frontiers specified in the Plan» that was being produced to resolve the issue of borders ${ }^{22}$.

Since I724, Dom Luís da Cunha had been collaborating with D'Anville for the latter to produce geographical materials that reflected Portugal's interests in the negotiations. His Amérique méridionale was the culmination of that process. Although dated I 748 it was only printed two years later, but in 1747 Dom Luís sent a draft copy to Cerveira in Madrid, described as «a small map to verify your favorable opinion ${ }^{93}$. Although expecting it to be used in the negotiations, in the latter it was finally decided by the Portuguese authorities, under Gusmão's supervision, to produce a «general map... that will be sufficient to demonstrate everything» that

\footnotetext{
90. CORTESÃo, 2001, t. 2: 365 .

91. ANTT, Ministério dos Negócios Estrangeiros, caixa 560, ME.III-A- Fr. C1, n. 111, Apr. 8, 1737.

92. ANTT, Ministério dos Negócios Estrangeiros, caixa 612, Feb. 8, 1749.

93. ANTT. Ministério dos Negócios Estrangeiros. livro 826, ff. 16-16v, Madrid, August 17, 1747.
} 
was claimed. Entitled Mapa dos Confins do Brazil com as terras da coroa de Espanha na América meridional, it became known as the Mapa das cortes because it was the one finally used by both Courts to «adjust the Treaty of the division of boundaries in South America signed [by the two courts] on January I3, I750»94. While Dom Luís da Cunha shared the Enlightenment view that maps should be perfect mirrors of the territory, Gusmão believed that political ends justified a cartography produced as a distorted mirror of the geographic reality as Mapa das cortes distorted the American continent to the east. Several important urban centers in the interior of Brazil were pushed eastward, and a number of other changes resulted from the fact that the map's longitudes were distorted, even though the latitudes were numbered. Hence all of Portuguese America was pushed eastward, and the area of Brazil that fell outside of Tordesillas was quite reduced, which gave the impression that the Portuguese had obtained few territorial gains to the west of that meridian. In contrast, D’Anville's Amérique méridionale, which reflected Dom Luís da Cunha's geopolitical vision, portrayed the Portuguese territory in the Americas with features that were much closer to what he and D'Anville believed were real, a portrayal that was permeated by mathematics and geometry.

The differences between these two maps reveal that, although Dom Luís da Cunha's political conceptions were mostly put in practice by the negotiators in Madrid through the influence of Alexandre de Gusmão himself, the two men differed in their geopolitical views of the territory and in the way they believed negotiations should be conducted. This dispute was, above all, a war of cartographic images. D'Anville did not shift Brazil to the east, leaving a significant part of Portuguese territory visibly beyond the Tordesillas Line. This practice reflected the maxims that, according to Dom Luís da Cunha, should guide the negotiations: without misrepresenting the geographic reality, they should be based on what had been agreed upon in previous treaties, respecting natural boundaries and the principle of uti possidetis.

Mapa das Cortes served as the basis for the establishment of the treaty and would come to be considered the map that had created this new Brazil. But the treaty also stipulated that bilateral expeditions ought to establish stone markers to demarcate these borders in America. When these groups began to take local measurements, the distortions of the Mapa das Cortes quickly became evident. The recognition by the Spanish of the enormous territory to the West they had surrendered to the Portuguese led to a strong campaign against the Treaty of Madrid. On the Portuguese side there was resistance to the handing over of Colônia do Sacramento.

In the long term, despite Portugal's efforts to establish the Mapa das cortes as a reflection of the American continent's features, it was the Amérique méridionale which, through the primacy of geography and mathematics, most closely represented Brazil's continental configuration, becoming, as the ambassador and the geographer wished, a historically possible mirror of the continent's geography and it was the map

94. ANTT, Ministério dos Negócios Estrangeiros, livro 826, f. 16-16v, Madrid, Aug. 17, 1747; f. 114v, Lisbon, Dec. $28,1748$. 
that indeed invented Brazil. 95 Interestingly enough, in all the border negotiations involving the Minister of Foreign Affairs in Brazil from the late nineteenth to the early twentieth century, D'Anville's maps were invoked as documentary proof of Brazil's right over the territories in dispute.

The same happened with the two men's geopolitical visions and the ways in which they envisioned conducting the negotiations differed considerably. Dom Luis, an experienced ambassador, saw it as a matter of presenting the territory with the greatest possible accuracy, sharing the information that the Portuguese had gathered with the Spanish, and attempting to resolve these conflicts diplomatically using the uti possidetis, although Brazil's shape on D'Anville's map was just invented by both ${ }^{96}$. Gusmão, meanwhile, saw a need to disguise the territory's true shape and conduct negotiations by taking advantage of the Spaniards' relative ignorance of significant portions of land, doing so in such a way that their adversaries would accept Portugal's claims. Using Gusmão's strategy the 1750 Treaty of Madrid did not put an end to the differences between the two crowns, and the disagreements regarding boundaries in South America continued throughout the second half of the eighteenth century. Proving its failure the 176r Treaty of El Pardo annulled what was agreed in 1750 and the new frontiers remained undefined until they were renegotiated in the 1777 Treaty of San Ildefonso that again invoked the uti possidetis ${ }^{97}$ and remained so in the nineteenth and twentieth centuries, in a post-Independence context, this time involving the young nations of the Americas.

95. FURTADO, 2013

96. FURTADO, 2012; FURTADO, 2013.

97. MunilLa, 1949 


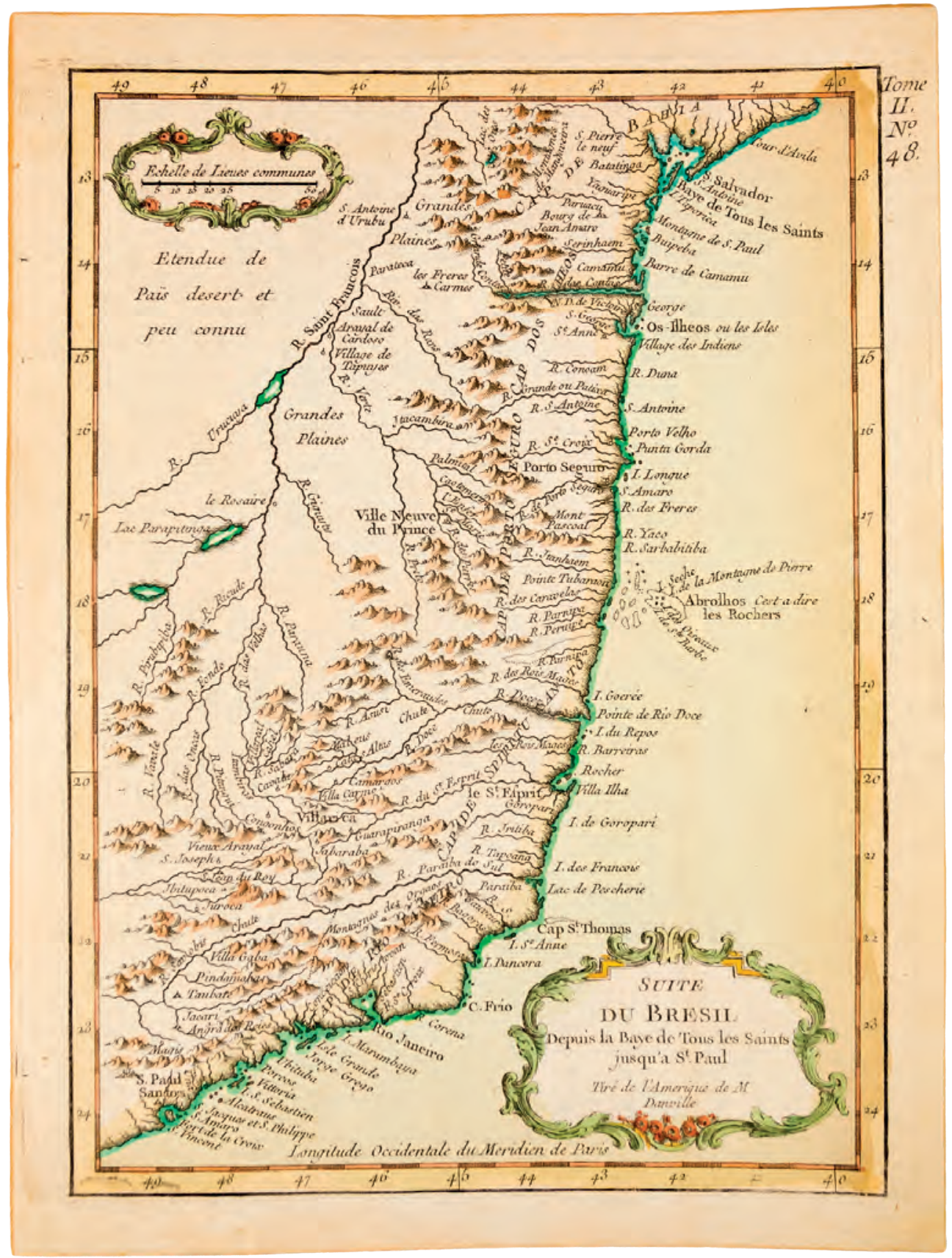

IMAGE 1. SUITE DU BRÉSIL, DEPUIS LA BAYE DE TOUS LES SAINTS JUSQU'A ST. PAUL, JEAN BAPTISTE BOURGUINON D'ANVILLE, CA.1748. Junia Furtado Collection

Legend: The region of Minas Gerais captaincy where gold was found early in XVIII century 


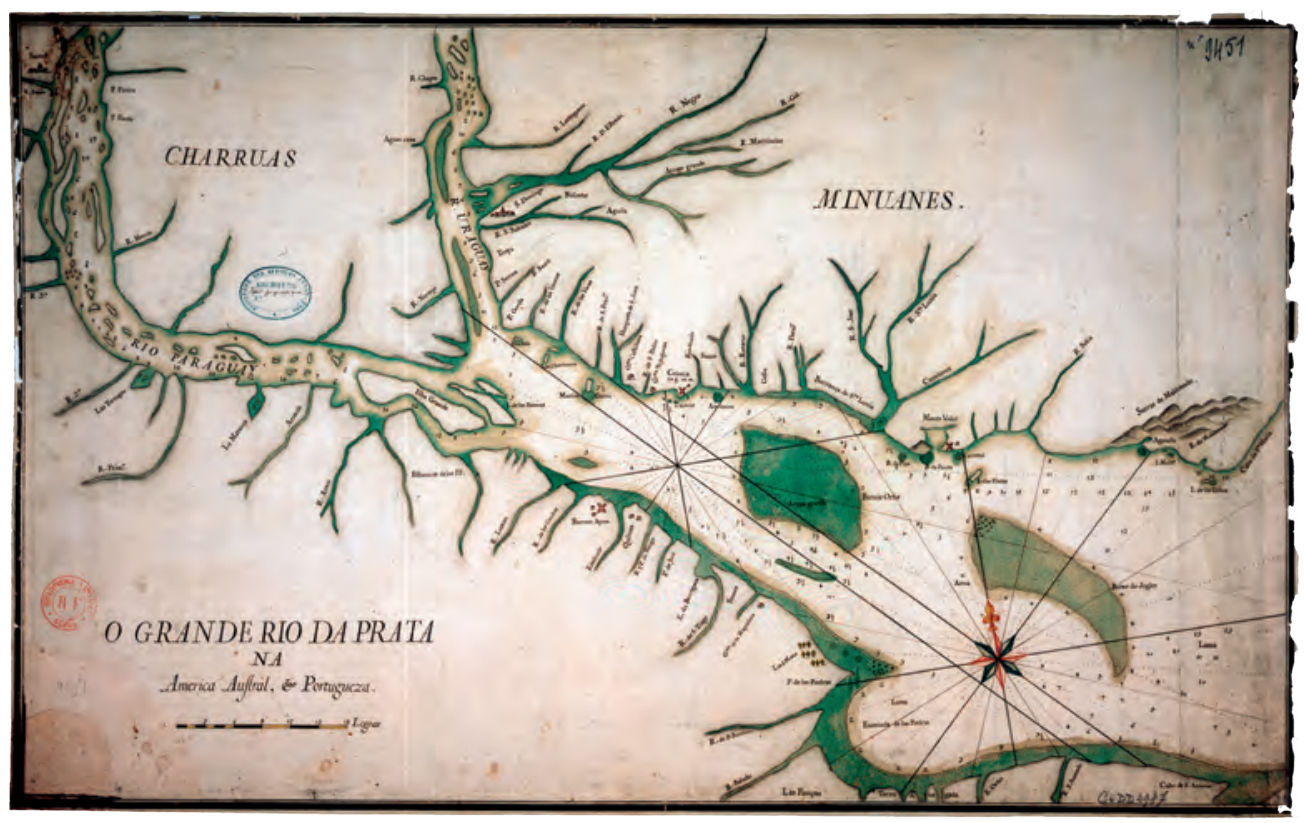

IMAGE 2. O GRANDE RIO DA PRATA NA AMÉRICA AUSTRAL E PORTUGUESA. Bibliothèque Nationale de France (BNF). Département des Cartes et Plans (DCP). GE DD 2.987 (9.451)

Legend: To the Portuguese Colônia do Sacramento comprised all the Northern bank of the River Plate

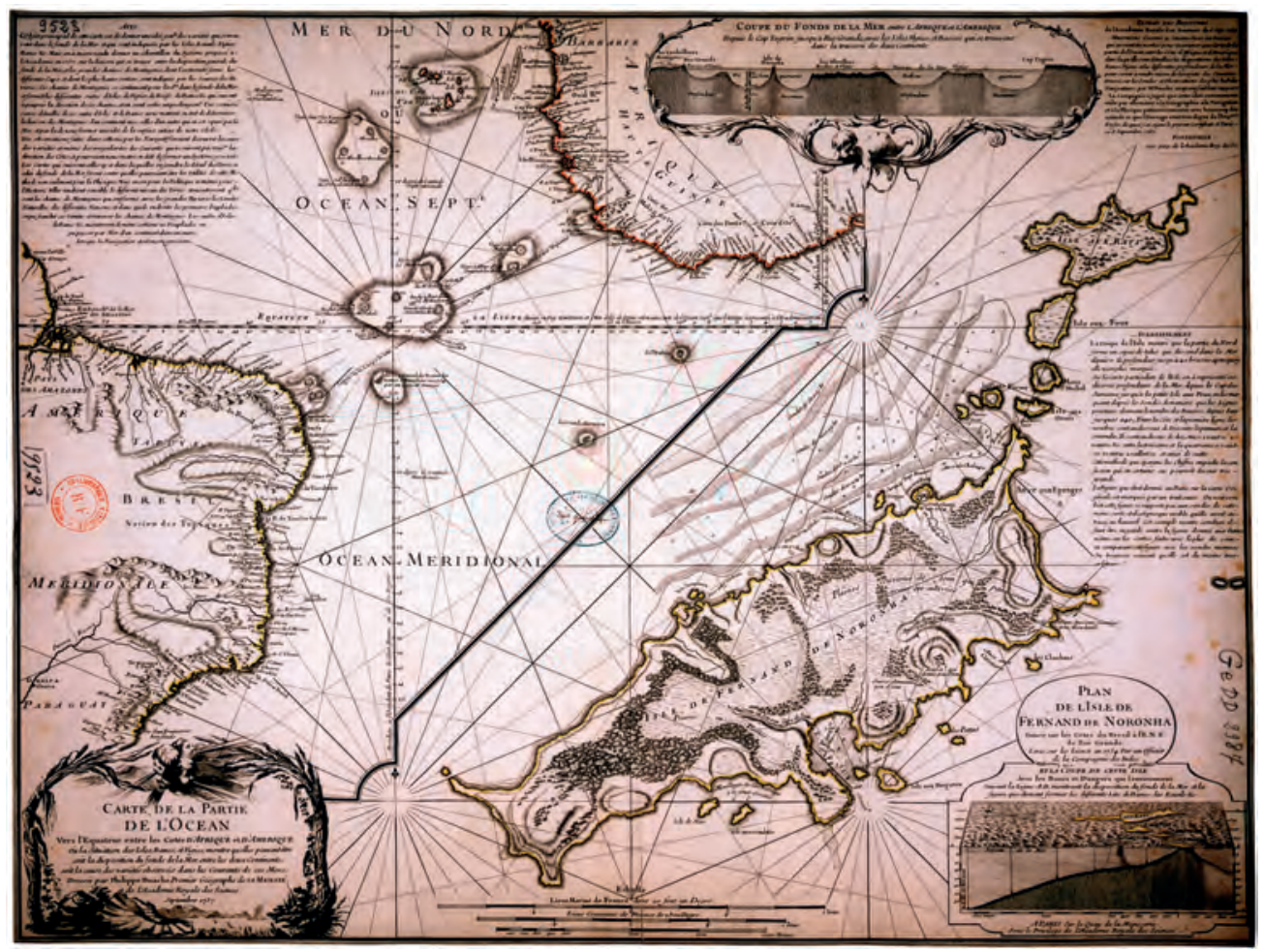

IMAGE 3. CARTE DE LA PARTIE DE L'OCEAN VERS L'ÉQUATEUR, PHILIPPE BUACHE. BNF. DCP. GE DD 2.987 (9.523). Legend: Dom Luís called attention to the fact that, as part of the act of possession, the French had renamed Fernando de Noronha island as Isle Dauphine 


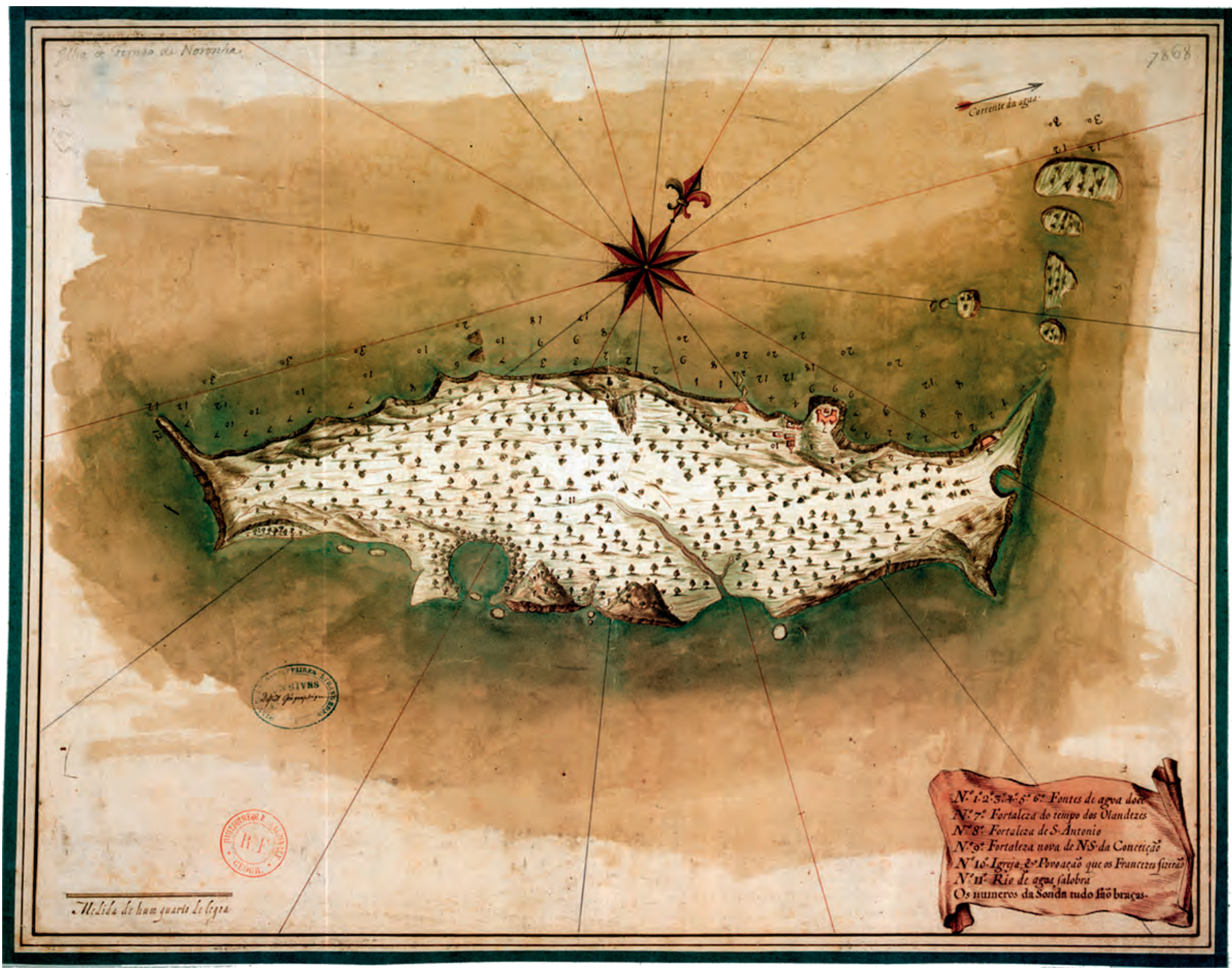

IMAGE 4. CARTE PORTUGAISE MANUSCRITE DE L'T̂SLE DE FERNÃO DE NORONHA, DETALHE E CARTELA. BNF. DCP. GE DD 2.987 (9.525)

Legend: The Portuguese map marks as number 10 the church and settlement made by the French 


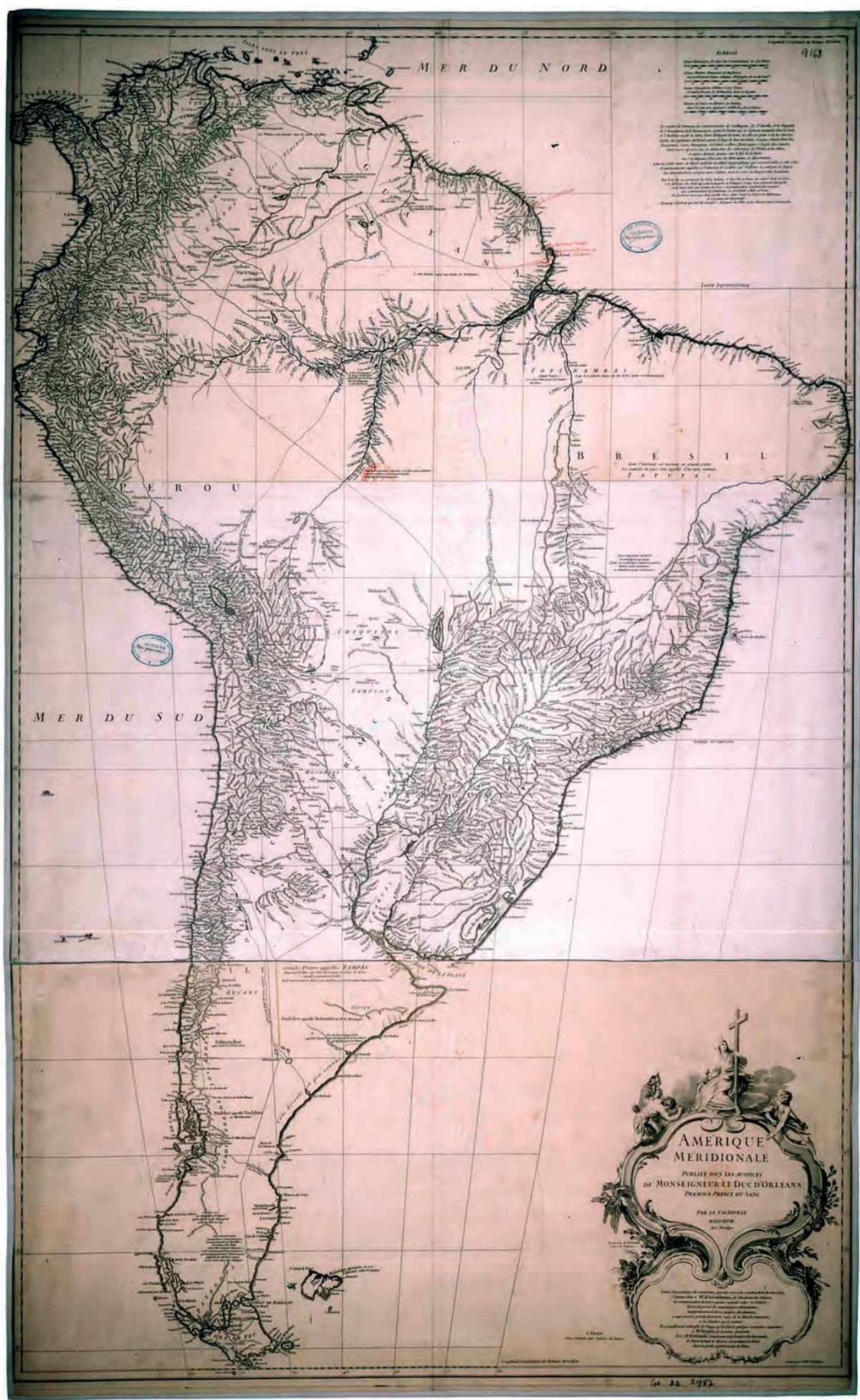

IMAGE 5. CARTE DE L'AMÉRIQUE MÉRIDIONALE, JEAN BAPTISTE BOURGUINON D'ANVILLE, 1748 [1779]. Junia Furtado Collection

Legend: Dom Luís da Cunha sent D’Anville's map Amérique méridionale to Madrid in 1748 hopping to be used as the base for the representation of this territory, since under his patronage it showed Brazil as precisely as possible 


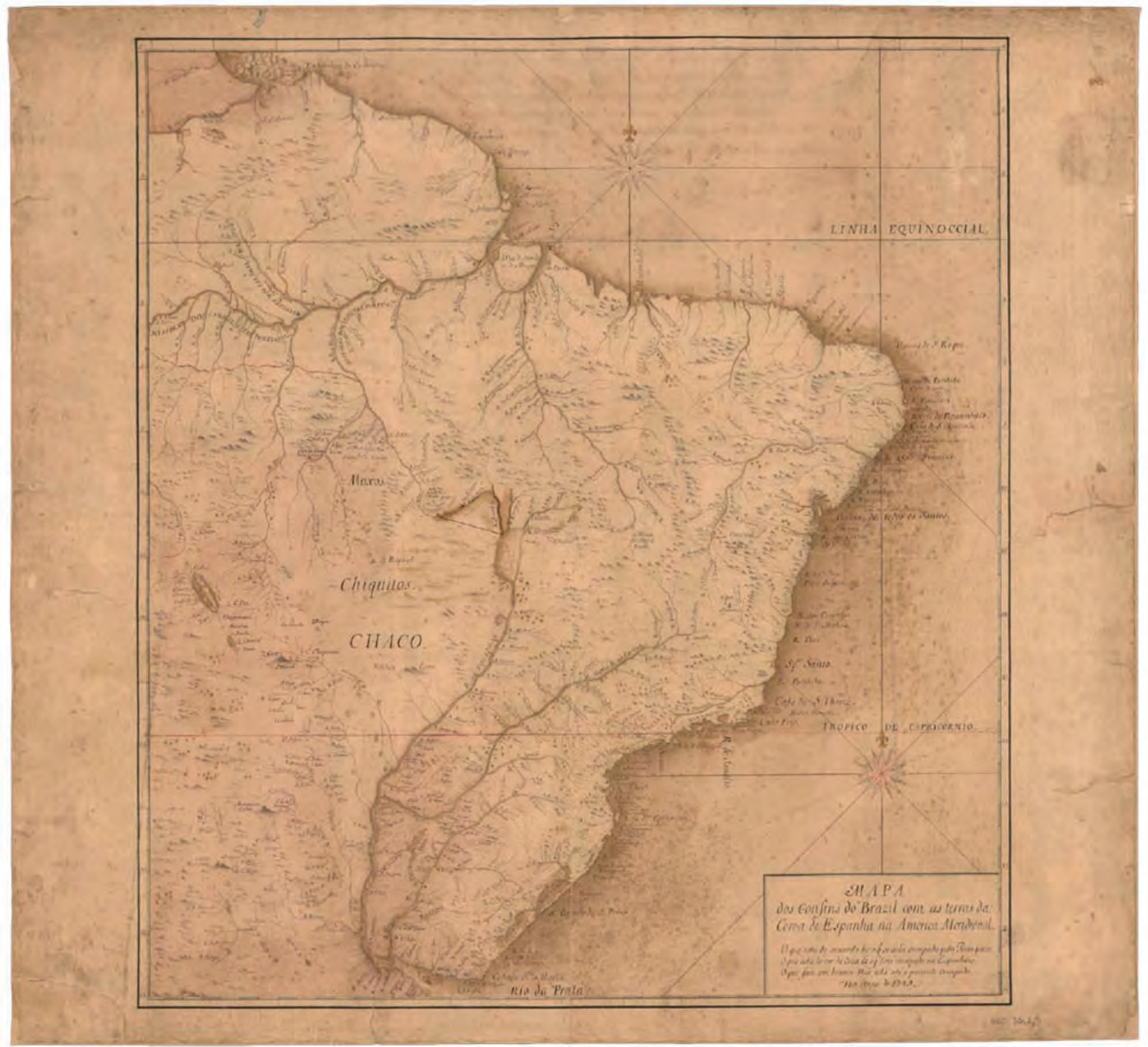

IMAGE 6. MAPA DOS CONFINS DO BRASIL COM AS TERRAS DA COROA DE ESPANHA NA AMÉRICA OU MAPA DAS CORTES. Fac-símile, Junia Furtado Collection

Legend: Mapa das Cortes made under Alexandre de Gusmão's surpervision distorted the American continent to the east, given to the Portuguese in the center west that became Brazilian territory 


\section{PRINTED WORKS AND BIBLIOGRAPHY}

AlmeidA, Luís Ferrand de, A Colônia do Sacramento na Época da Sucessão de Espanha, Coimbra, Instituto Histórico Dr. António de Vasconcelos, Faculdade de Letras da Universidade de Coimbra, I957.

Bluteau, Raphael, Vocabulário Português e Latino, Coimbra, Colégio das Artes da Companhia de Jesus, I7I2.

CARDIM, Pedro, «La jurisdicción real y su afirmación em la Corona portuguesa y sus territorios ultramarinos (siglo XVI-XVIII): reflexiones sobre la historiografía», in Francisco José Aranda Pérez and José Damião Rodrigues (eds.) De Re Publica Hispaniae: una vindicación de la cultura política en los reinos ibéricos en la primera modernidad, Madrid, Sílex, 2008, 349-388.

Cluny, Isabel, D. Luís da Cunha e a idéia de diplomacia em Portugal, Lisboa: Livros Horizontes, I999.

Cortesão, Jaime, Alexandre de Gusmão e o Tratado de Madrid, Rio de Janeiro, Ministério das Relações Exteriores, I950-1963, parte III, tomo I.

Cortesão, Jaime, Alexandre de Gusmão e o Tratado de Madrid, Rio de Janeiro, Ministério das Relações Exteriores, I950-I963, parte IV, tomo I.

Cortes̃̃o, Jaime, Alexandre de Gusmão e o Tratado de Madrid, Lisboa, Livros Horizonte, I984, 4 vols.

Cortesão, Jaime, O Tratado de Madrid, Brasília, Senado Federal, 20oI, 2 vols.

CunHA, Luís da, Instruções políticas (edição de Abílio Diniz Silva), Lisboa, Comissão Nacional para as Comemorações dos Descobrimentos Portugueses (CNPCDP), 2001.

Dion, Roger, Les frontières de la France, Paris, Hachette, I947.

Ferreira, Mário Clemente, O Tratado de Madrid e o Brasil Meridional, Lisboa, CNPCDP, $200 \mathrm{.}$.

Furtado, Junia Ferreira, Oráculos da Geografia iluminista: Dom Luís da Cunha e Jean Baptiste Bourguignon D’Anville na construção da cartografia do Brasil, Belo Horizonte, Ed. UFMG, 2012.

FurTado, Junia Ferreira, The map that invented Brazil, São Paulo/Rio de Janeiro, Odebrecht/ Versal, 2013.

Furtado, Junia Ferreira, «'O oráculo que Sua Majestade foi buscar’: Dom Luís da Cunha e a geopolítica do novo império luso-brasileiro», in João Luís Ribeiro Fragoso e Maria de Fátima Gouvêa (eds.), Na trama das redes: política e negócios no império português, séculos XVI-XVIII, Rio de Janeiro, Civilização Brasileira, 2010, 373-400.

FURTADO, Junia Ferreira, «Dom João V e a década de I720: novas perspectivas na ordenação do espaço mundial», in João Luís Ribeiro Fragoso e Maria de Fátima Gouvêa (eds.), O Brasil Colonial (I720-I82I), Rio de Janeiro, Editora Civilização Brasileira, 20I4, vol. III: 6I-IIo.

FURTADO, Junia Ferreira, «Metamorphoses of colonization: the Tocantins River and the expansion to the West in maps and reports (I ${ }^{\text {th }}$ century)», Tempo, 22/40 (2016):367-399.

Goes Filho, Synesio Sampaio, Navegantes, bandeirantes, diplomatas: um ensaio sobre a formação das fronteiras do Brasil, Brasília, FUNAG, 2015.

LıмA, Sérgio Eduardo Moreira, «Apresentação», in Synesio Sampaio Goes Filho, Navegantes, bandeirantes, diplomatas: um ensaio sobre a formação das fronteiras do Brasil, Brasília, FUNAG, 2015: 5-8.

Martín Marcos, David, «La paz hispanoportuguesa de I715: la diplomacia ibérica en Utrecht», Cuadernos de Historia Moderna, 37 (2012): 15I-I75. 
Munilla, Octavio Gil, El Río de la Plata en la política internacional. Génesis del virreinato, Sevilla, Consejo Superior de Investigaciones Científicas - Escuela de Estudios HispanoAmericanos de Sevilla, I949.

PedReIRA, Jorge M, «Brasil, fronteira de Portugal. Negócio, emigração e mobilidade social (séculos XVIl e XVIII)», in Mafalda Soares da Cunha et alii (eds), Do Brasil à metrópole: efeitos sociais (séculos XVII-XVIII), Évora, Universidade de Évora, 200I, 47-72.

Possamal, Paulo, $A$ vida cotidiana na Colónia do Sacramento: um bastião português em terras do futuro Uruguai, Lisboa, Bertrand, 2006.

Prado, Fabrício, Colônia do Sacramento: o extremo sul da América portuguesa, Porto Alegre, F. P. Prado, 2002.

RoDRigues, José Damião, «Diplomacia, geopolítica e migrações: colonos portugueses no povoamento do Brasil meridional entre os tratados de Utrecht e de Madrid» in Abílio Diniz Silva, Ana Leal de Faria e Tiago C. P. dos Reis Miranda (eds.), D. Luís da Cunha e as negociações de Utreque. Lisboa: Biblioteca Nacional de Portugal, 20I4, I3I-I55

SeEd, Patrícia, Cerimônias de posse na conquista europeia do Novo Mundo (I492-I640), São Paulo, Unesp, I999.

SıLVA, Abílio Diniz, «Introdução», in Luís da Cunha, Instruções políticas (edição de Abílio Diniz Silva), Lisboa, CNPCDP, 200I a, 9-II7.

Silva, Abílio Diniz, «D. Luís da Cunha e o Brasil», en Maria Beatriz Nizza da Silva (ed.), De Cabral a Pedro I: aspectos da colonização portuguesa no Brasil, Porto, Universidade Portucalense, 200I b, 26I-276.

Todorov, Tzvetan, A conquista da América: a questão do outro, São Paulo, Martins Fontes, I983. 


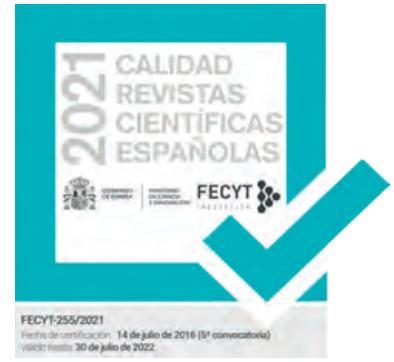

SERIE IV HISTORIA MODERNA

REVISTA DE LA FACULTAD DE GEOGRAFÍA E HISTORIA

AÑO 2021

ISSN: 1131-768X

E-ISSN 2340-1400

\section{4 \\ 西 ESPACIO, TIEMPO Y FORMA}

Monográfico - Special Issue: La política ultramarina de las monarquías ibéricas (circa 1700-1750): una historia de fracasos y éxitos relativos The Overseas Policy of the Iberian Monarchies (Circa 1700-1750): A History of Failures and Relative Successes

15 Roberto Quirós Rosado y MARIA FERnANDA BICALHO La política ultramarina de las monarquías ibéricas (circa 1700-1750): una historia de fracasos y éxitos relativos / The Overseas Policy of the Iberian Monarchies (Circa 1700-1750): A History of Failures and Relative Successes

\section{Guillaume Hanotin}

Defender negocios en tiempo de convulsión política: las elites mercantiles francesas durante la guerra de Sucesión española / Protecting Business in Time of Crisis: French Trademen during the War of Spanish Succession

\subsection{Maria Fernanda Bicalmo}

Ultramarino y el auge de los secretarios de Estado en Portugal durante la primera mitad del siglo XVIII / Sobre este modo de resolver e despachar os negócios. The decline of the Overseas Council and the Rise of the Secretaries of State in Portugal during the First Half of the $18^{\text {th }}$ Century

\section{9}

\section{VALENTINA FAVARò}

El fracaso de los proyectos de reforma en el virreinato peruano de principios

del siglo XVIII. Las propuestas de Carmine Nicola Caracciolo, príncipe de Santobuono the Eighteenth Century. The Proposals of Carmine Nicola Caracciolo, Prince of Santobuono

\section{7}

\section{ROBERTO QUIRÓS ROSADO}

Ecos de un mercantilismo truncado. El conde de Pinos Puente y la diplomacia comercial de Carlos VI en la corte de Lisboa (1723-1724) / Echoes of a Failed Mercantilism. The Count of Pinos Puente and the Commercial Diplomacy of Charles VI at the Court Of Lisbon (1723-1724)

\section{Junia Ferreira Furtado}

Portuguese America under Foreign Threat and the Creation of the Concept of uti possidetis in the First Half of the $18^{\text {th }}$ Century / La américa portuguesa bajo la amenaza exterior y la creación del concepto de uti possidetis en la primera mitad del siglo XVIII

\section{Miscelánea $\cdot$ Miscellany}

\section{José Antonio Mateos Royo}

con Cataluña / Trade Policy and Monetary Circulation in Aragon: Conflicts and Agreements with Catalonia (1535-1565)

\section{Fernando Altoé}

panegíricos atribuidos a la impresion. Un estudio de la trayectoria de dos the Trajectory of Two Panegyrics Attributed to João de Barros

\section{Francisco Velasco Hernández}

reino de Murcia (siglos XVI y XVII) / The Influence of the Berber Corsican on the Late Repopulation on the Coastal Area on the Kingdom of Murcia (XVI and XVII Centuries)

\section{José Antonio Martínez Martínez}

Criados, jornaleros y esclavos al servicio de la familia: la servidumbre de Serfdom of the Muñoz de Otálora in the $17^{\text {th }}$ Century

\section{Víctor Daniel Regalado González-Serna}

Benito de Medina a raíz de su ingreso en el cabildo catedral de Sevilla en 1669 / «Not a Single Good Portuguese». Accusations against Priest Alonso Benito de Medina when Entering the Cathedral Chapter of Seville in 1669

\section{José Herrera Reviriego}

organigrama comercial y militar de la Gobe mitad del siglo XVII / "Only Time will Tell us»: The Role of Taiwan within the Commercial and Military Organization of the Philippine's Governoration during the First Half of the Seventeenth Century

\section{Manuel-Reyes García Hurtado}

de Rande, 1719-1733 / Vicissitudes of the Rescue Companies of the Sunken Ships in the Battle of Rande, 1719-1733

\subsection{Marcos de Miguel MuÑoz}

Caballeros in 1769 


\section{4 ESPACIO, TIEMPO Y FORMA}

\section{Javier Tinoco Domínguez}

Tensiones sociopolíticas en el marco del catastro de Fnsenada en Jerez de la Frontera: estudio de un conflicto institucional / Socio-Political Tensions within the Framework of Cadastre of Ensenada In Jerez de la Frontera: A Studying of an Institucional Conflict

\section{Pablo Fernández Albaladejo}

Fábulas de origen y gramática de nación en la España del siglo XVIII. A propósito de algunos trabajos de Francisco Martínez Marina / Origin's Fables and Grammar of Nation in the XVIII Century Spain. About some Works by Francisco Martínez Marina

\subsection{José María IÑURRITEgui Rodríguez}

3 Constitución increada: Francisco Martínez Marina y la crítica bíblica / Uncreated Constitution. Francisco Martínez Marina and Biblical Criticism

\subsection{David A. Abián Cubillo}

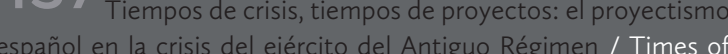
crisis, Times of Projects: The Spanish proyectismo during the Army's Crisis in the Ancient Regime

Taller de historiografía · Historiography Workshop

Ensayos · Essays

\subsection{Christoph ROSEnMüLler}

«Tan peligrosas y feas conspiraciones»: la relación escrita por el embajador austriaco Christoph Migazzi en 1754 sobre la caída del marqués de la Ensenada / «Dangerous and Ugly Conspiracies». The Report of the Austrian Ambassador Christoph Migazzi on the Fall of the Marquis of la Ensenada in 1754

\subsection{Serge Gruzinskı}

Quelle histoire enseigner en 2021 ? / ¿Qué historia enseñar en 2021?

\subsection{Carlos Amate Pizarro}

Las relaciones hispano-chinas en el siglo XVI: síntesis e interpretación a la luz de la reciente historiografía / The Hispanic-chinese Relationship in the XVI Century: Synthesis and Interpretation in the Light of Recent Historiography

\section{Reseñas • Book Review}

521 Bolufer Peruga, Mónica, Arte y artificio de la vida en común. Los modelos de comportamiento y sus tensiones en el Siglo de las Luces, (Julio ArRoyo VozmediANo) 


\section{4 ESPACIO, TIEMPO Y FORMA}

525 Melón, Amando, Alejandro de Humboldt. Vida y obra (Carlos Martínez Shaw)

52 Commentary to Tatiana Seijas' review of The Atlantic World and the Manila Galleons: Circulation, Market, and Consumption of Asian Goods in the Spanish Empire (JosÉ LuIs GASCH TOMAS)

533 Braguier, Laurey, Servantes de dieu. Les beatas de la Couronne de Castille (1450-1600) (Manuela Águeda GARCÍA-GARRIDO)

539 Romeo, María CRuz; SAlomón, María Pilar; TABANERA, Nuria (eds.): Católicos, Reaccionarios y Nacionalistas. Política e identidad nacional en Europa y América Latina Contemporáneas (JAVIER M. Dos SANTOS)

54 Heredia López, Alfonso Jesús, El control de la corrupción en la Monarquía Hispánica. La Casa de la Contratación (1642-1660) (José Manuel Díaz Blanco)

17 Andújar Castillo, Francisco, El Atila de Madrid. La forja de un banquero en la crisis de la monarquía (1685-1715) (Aitor Díaz PAREdes)

551 Serrano Aviles, Javier y Mojarro, Jorge (eds.) Prada GonzALEZ, María (coord. de ilustraciones), En el archipiélago de la Especiería. España y Molucas en los siglos XVI y XVII (İ̃̃ıGo VALPUESTA VILLA)

555 Díaz Ceballos, Jorge, Poder compartido. Repúblicas urbanas, Monarquía y conversación en Castilla del Oro, 1508-1573 (JUAN SEbAstián Gómez GonZÁleZ)

61 Edelmayer, Friedrich, Massimiliano II, Filippo II I'Italia imperiale. II marchesato di Finale, i diritti imperiali e il «camino spagnolo» (RAFAEL VALLADARES)

56 Escribano-PÁEZ, José M., Juan Rena and the Frontiers of Spanish Empire, 1500-1540 (DAvid Martín Marcos)

56 ARnOLD, David, La Era de los Descubrimientos (1400-1600), Madrid, Alianza Editorial, 2021, 184 Pp., ISBN: 978-841362-172-2 (CARlos Amate Pizarro) 